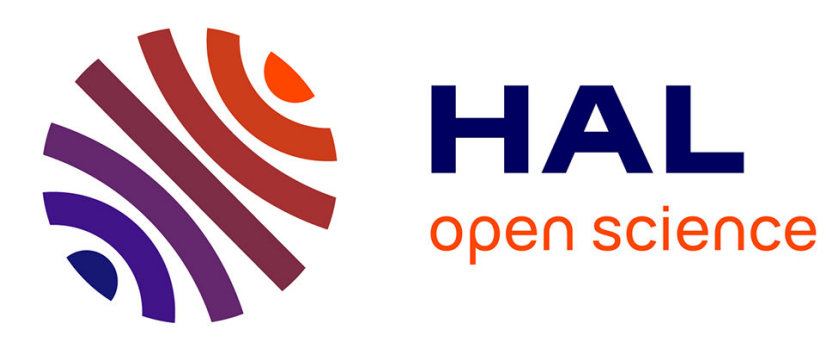

\title{
Mutual solubility of water and hydrophobic ionic liquids in the presence of hydrochloric acid
}

Valérie Mazan, Maria Yu Boltoeva, Evgeny E Tereshatov, Charles M Folden Iii

\section{To cite this version:}

Valérie Mazan, Maria Yu Boltoeva, Evgeny E Tereshatov, Charles M Folden Iii. Mutual solubility of water and hydrophobic ionic liquids in the presence of hydrochloric acid. RSC Advances, 2016, 6 (61), pp.56260-56270. 10.1039/c6ra06791c . hal-03009864

\section{HAL Id: hal-03009864 \\ https://hal.science/hal-03009864}

Submitted on 17 Nov 2020

HAL is a multi-disciplinary open access archive for the deposit and dissemination of scientific research documents, whether they are published or not. The documents may come from teaching and research institutions in France or abroad, or from public or private research centers.
L'archive ouverte pluridisciplinaire HAL, est destinée au dépôt et à la diffusion de documents scientifiques de niveau recherche, publiés ou non, émanant des établissements d'enseignement et de recherche français ou étrangers, des laboratoires publics ou privés. 


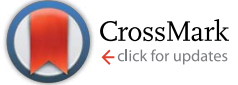

Cite this: RSC Adv., 2016, 6, 56260

\title{
Mutual solubility of water and hydrophobic ionic liquids in the presence of hydrochloric acid $\uparrow$
}

\author{
Valérie Mazan, ${ }^{\text {ab }}$ Maria Yu. Boltoeva, ${ }^{\text {*ab }}$ Evgeny E. Tereshatov ${ }^{c}$ and Charles M. Folden \\ III
}

Previous studies have shown that the presence of nitric acid, the principal solute in various hydrometallurgical processes, and perchloric acid in the aqueous phase is an important factor for increased aqueous solubility of hydrophobic ionic liquids. In this study, the effect of hydrochloric acid in the aqueous phase on the mutual solubility of water and hydrophobic 1,3-dialkylimidazolium- and N,Ndialkylpyrrolidinium bis(trifluoromethylsulfonyl)imide ionic liquids, $\left[\mathrm{C}_{n} \operatorname{mim}\right]\left[\mathrm{Tf}_{2} \mathrm{~N}\right](n=2,4,6$, and 8 ) and $\left[\mathrm{C}_{3} \mathrm{C}_{1}\right.$ pyrr] $\left[\mathrm{Tf}_{2} \mathrm{~N}\right]$, is examined at room temperature and atmospheric pressure. Hydrochloric acid caused a considerable increase in the aqueous solubility of all the studied ionic liquids. The amount of water transferred into the organic phase increases with increasing hydrochloric acid concentration for short alkyl chain ILs, and the opposite trend was observed for long alkyl chain ILs. The effect of the $\mathrm{N}-\mathrm{H}$ acid bis(trifluoromethylsulfonyl)imide, $\mathrm{H}\left[\mathrm{Tf}_{2} \mathrm{~N}\right]$, and the salts lithium bis(trifluoromethylsulfonyl)imide, Li[Tf $\left.2 \mathrm{~N}\right]$, and 1-butyl-3-methylimidazolium chloride, $\left[\mathrm{C}_{4} \mathrm{mim}\right] \mathrm{Cl}$, dissolved in hydrochloric acid solutions on the mutual solubility of water and the $\left[\mathrm{C}_{4} \mathrm{mim}\right]\left[\mathrm{Tf}_{2} \mathrm{~N}\right]$ ionic liquid were also investigated. The salting-out effect is observed and it was shown to be dependent on the nature of the salt, its concentration and the hydrochloric acid concentration in the aqueous phase. A mathematical model has been developed to describe the dependence of the ionic liquid cation and anion concentration on the common ion salt concentration in the aqueous hydrochloric acid phase. This model describes the basic character of ionic liquid dissolution in the aqueous phase and allows for estimation of solubility product values.

Received 14th March 2016 Accepted 6th June 2016

DOI: 10.1039/c6ra06791c

www.rsc.org/advances
Ionic liquids can be applied in various chemical fields such as organic synthesis, ${ }^{8}$ catalysis, ${ }^{9,10}$ electrochemistry, ${ }^{11,12}$ and separation chemistry, ${ }^{13}$ particularly solvent extraction..$^{14-16}$ Hydrophobic ionic liquids are widely considered as a promising alternative to traditional organic solvents because of their unique physicochemical properties like high chemical and thermal stability, ${ }^{17}$ non-flammability, ${ }^{18,19}$ very low vapor pressure. ${ }^{20,21}$ These properties may offer safer and more efficient ways to extract metallic ions from acidic aqueous solutions..$^{1,22,23}$ However, the use of ionic liquids could result in complications for a global extraction process, especially because of: (i) the modification of some thermophysical and transport properties of ionic liquid phase, for example, density and viscosity, ${ }^{24,25}$ after contact with aqueous solutions; (ii) the mutual solubility of water and IL and as consequence the pollution of the aqueous phase with IL ions; (iii) the complex mechanism of extraction of metallic ions. These issues must be considered from various points of view prior to the application of ILs for metal separation: (i) from the technological point of view, because of possible phase reversal and undesirable presence of IL component ions in product streams; (ii) from the environmental point of view because of the possible release of ILs in aquatic systems; and (iii) from the economical point of view because of the loss of costly ILs. Moreover, the mutual solubility
${ }^{a}$ Université de Strasbourg, IPHC, 67037 Strasbourg, France.E-mail: maria.boltoeva@ iphc.cnrs.fr; Tel: +33388106404

${ }^{b}$ CNRS, 67037 Strasbourg, France

${ }^{c}$ Cyclotron Institute, Texas A\&M University, College Station, TX 77843, USA

$\dagger$ Electronic supplementary information (ESI) available. See DOI: $10.1039 / \mathrm{c} 6 \mathrm{ra06791c}$ 
of water and ILs is of key importance because the metal extraction can be driven by transfer of IL constituent ions into the aqueous phase. ${ }^{26}$

1,3-Dialkylimidazolium bis(trifluoromethylsulfonyl)imide ionic liquids are the most studied ILs as solvents for the extraction of metals. These ILs are hydrophobic but somewhat hygroscopic and slightly soluble in water. In our previous works, ${ }^{26,27}$ the mutual solubility of 1-butyl- and 1-decyl-3methylimidazolium bis(trifluoromethylsulfonyl)imide ILs and water in the presence of nitric, perchloric, and hydrochloric acids was investigated. It was shown that these mineral acids widely used in solvent extraction are an important factor for increased solubility of the studied ionic liquids. Nevertheless, the experimental data on the behavior of biphasic systems composed of IL and hydrochloric acid solutions are limited and fragmentary. ${ }^{27,28}$ There are no data on the IL anion solubility as a function of hydrochloric acid concentration, the impact of cation alkyl side chain length and the presence of various organic and inorganic solutes in both phases on the solubility of ILs. However, a number of recent studies have reported the extraction of metals such as gold, platinum, iridium and thallium from hydrochloric acid media into pure ILs. ${ }^{2,29,30}$ To understand the mechanism of extraction in this kind of ILbased systems, the study of mutual solubility of water and IL in the presence of hydrochloric acid is mandatory.

This paper reports the study of biphasic systems composed of aqueous hydrochloric acid solutions (concentrations from 0 to $10.5 \mathrm{M}$ ) and hydrophobic bis(trifluoromethanesulfonyl) imide-based ILs composed of four 1-alkyl-3methylimidazolium cations with $2,4,6$, and 8 carbons in the alkyl chain and also the $N$-propyl- $N$-methylpyrrolidinium cation. The determination of the equilibrium concentration of the entities, namely $\mathrm{H}_{2} \mathrm{O}$, in the ionic liquid phase, and cations and anions of ILs and hydrochloric acid in the aqueous phase, as a function of the solutes dissolved in the aqueous phase was carried out. The results obtained in this work give some insights into the behavior of IL-based extraction systems in contact with aqueous hydrochloric acid solutions.

\section{Experimental section}

\subsection{Chemical products}

High purity grade (99.5\%) ionic liquids, 1-alkyl-3methylimidazolium bis(trifluoromethanesulfonyl)imide (henceforth indicated as $\left[\mathrm{C}_{n} \mathrm{mim}\right]\left[\mathrm{Tf}_{2} \mathrm{~N}\right]$, where $n=2,4,6$, and 8), $N$ propyl- $N$-methylpyrrolidinium bis(trifluoromethanesulfonyl) imide $\left(\left[\mathrm{C}_{3} \mathrm{C}_{1}\right.\right.$ pyrr $\left.]\left[\mathrm{Tf}_{2} \mathrm{~N}\right]\right)$, and salts, 1-butyl-3-methylimidazolium chloride $\quad\left(\left[\mathrm{C}_{4} \mathrm{mim}\right] \mathrm{Cl},>99 \%\right)$ and lithium bis(trifluoromethanesulfonyl)imide $\left(\operatorname{Li}\left[\mathrm{Tf}_{2} \mathrm{~N}\right],>99 \%\right)$, were purchased from Solvionic (Toulouse, France). The $\mathrm{N}-\mathrm{H}$ acid bis(trifluoromethylsulfonyl)imide $\left(\mathrm{H}\left[\mathrm{Tf}_{2} \mathrm{~N}\right],>95 \%\right)$ was purchased from Sigma Aldrich. Fig. 1 shows the chemical structures of ILs used in the present study.

Selected physico-chemical properties of the ILs studied in this work (solubility of water, aqueous solubility, cation hydrophobicity, density, viscosity, and interfacial tension between IL and water) are provided in Table 1.

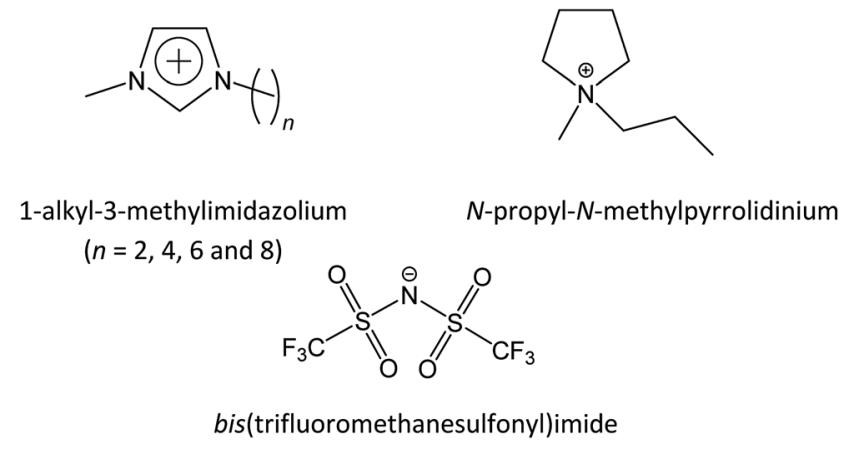

Fig. 1 Chemical structures of the ionic liquid cations and anion used in the present work.

Deuterium oxide (deuterated water, $\mathrm{D}_{2} \mathrm{O}$, Eurisotop) and deuterium chloride (deutero-hydrochloric acid, DCl, $35 \mathrm{wt} \%$ in $\mathrm{D}_{2} \mathrm{O}$ ) of analytical grade (purchased from Sigma Aldrich) were of 99 at\% purity of deuterium. Dihydrated sodium citrate (99\%) and maleic acid (99.9\%) were purchased from Merck, and sodium trifluoroacetate (98\%) was purchased from Alfa Aesar. All reagents were used without further purification. Deionized water (ELGA PURELAB DV25) with a resistivity of $18.2 \mathrm{M} \Omega \mathrm{cm}$ was used for preparing the aqueous solutions, except for the NMR samples.

\subsection{Sample preparation}

ILs were accurately dried under vacuum prior to use following a previously published procedure. ${ }^{38}$ The content of residual water was less than $0.03 \mathrm{wt} \%$ after drying $\left[\mathrm{C}_{n} \mathrm{mim}\right]\left[\mathrm{Tf}_{2} \mathrm{~N}\right](n=2$, $4,6$, or 8$)$ and $\left[\mathrm{C}_{3} \mathrm{C}_{1}\right.$ pyrr $]\left[\mathrm{Tf}_{2} \mathrm{~N}\right]$. The deutero-hydrochloric acid solutions were prepared by diluting concentrated $\mathrm{DCl}$ with deuterium oxide to the desired concentration. $\operatorname{Li}\left[\mathrm{Tf}_{2} \mathrm{~N}\right]$ and $\left[\mathrm{C}_{4} \mathrm{mim}\right] \mathrm{Cl}$ salts were dried under reduced pressure at room temperature for $4 \mathrm{~h}$. The solutions of $\operatorname{Li}\left[\mathrm{Tf}_{2} \mathrm{~N}\right]$ and $\left[\mathrm{C}_{4} \mathrm{mim}\right] \mathrm{Cl}$ were obtained by exact weighing of a calculated amount of solid followed by dissolving in a volumetric flask with $1 \mathrm{M}$ or $5 \mathrm{M} \mathrm{DCl}$ in $\mathrm{D}_{2} \mathrm{O}$. An analytical balance (Sartorius, BP 2215 model) with an accuracy of $\pm 0.1 \mathrm{mg}$ was used for weighing the components. The concentration of stock salt solutions was close to $1 \mathrm{M}$; these solutions were then diluted with $1 \mathrm{M}$ or $5 \mathrm{M}$ DCl in $\mathrm{D}_{2} \mathrm{O}$. The partition experiments were carried out by a standard liquid-liquid extraction technique. Generally, equal volumes of IL and aqueous phase $(0.8 \mathrm{~mL})$ were placed into Eppendorf centrifugation tubes $(2 \mathrm{~mL})$. The corresponding $\mathrm{IL}$ masses were calculated using the known densities (Table 1) and were taken precisely by weighing. The aqueous acidic solution was added into the tube by an Eppendorf Research precision pipette. The biphasic samples were vigorously mixed for $1 \mathrm{~h}$ at $1500 \mathrm{rpm}$ on a mechanical shaker (IKA vibrax VXR basic) at room temperature $\left(23 \pm 2{ }^{\circ} \mathrm{C}\right)$. After a given shaking time, the samples were centrifuged for $2 \mathrm{~min}$ at $3000 \mathrm{rpm}$ (Micro Star 12, VWR) in order to promote phase separation. Then, aliquots of the equilibrium organic and aqueous phases were taken for further analysis. The experiments were generally repeated twice. 
Table 1 Solubility of water in ILs, solubility of ILs in pure water, cation hydrophobicity, density, viscosity, and interfacial tension at $25^{\circ} \mathrm{C}$ of the ILs studied in this work

\begin{tabular}{|c|c|c|c|c|c|c|}
\hline Ionic liquid & $\begin{array}{l}\text { Solubility } \\
\mathrm{H}_{2} \mathrm{O} \text { in IL (M) }\end{array}$ & $\begin{array}{l}\text { Solubility } \\
\text { IL in } \mathrm{H}_{2} \mathrm{O}(\mathrm{mM})\end{array}$ & $\begin{array}{l}\text { Cation hydrophobicity, } \\
\log k_{0, \mathrm{c}}\end{array}$ & $\begin{array}{l}\text { Density } \\
\left(\text { dry, } \mathrm{g} \mathrm{cm}^{-3}\right)\end{array}$ & $\begin{array}{l}\text { Viscosity } \\
\text { (mPa s) }\end{array}$ & $\begin{array}{l}\text { Interfacial } \\
\text { tension }{ }^{33}\left(\mathrm{mN} \mathrm{m}^{-1}\right)\end{array}$ \\
\hline$\left[\mathrm{C}_{2} \mathrm{mim}\right]\left[\mathrm{Tf}_{2} \mathrm{~N}\right]$ & 1.60 (ref. 34) & 42 (ref. 35) & 0.22 & 1.52 & 34.40 (ref. 36) & 9.85 \\
\hline$\left[\mathrm{C}_{4} \mathrm{mim}\right]\left[\mathrm{Tf}_{2} \mathrm{~N}\right]$ & 1.20 (ref. 34) & 16 (ref. 26) & 0.67 & 1.44 & 51.82 (ref. 24) & 13.20 \\
\hline$\left[\mathrm{C}_{6} \mathrm{mim}\right]\left[\mathrm{Tf}_{2} \mathrm{~N}\right]$ & 0.79 (ref. 34) & 5 (ref. 35) & 1.2 & 1.36 & 70.26 (ref. 36) & 14.82 \\
\hline$\left[\mathrm{C}_{8} \mathrm{mim}\right]\left[\mathrm{Tf}_{2} \mathrm{~N}\right]$ & 0.63 (ref. 34) & 2.5 (ref. 28) & 1.9 & 1.31 & $104.00^{a}$ & 15.79 \\
\hline
\end{tabular}

For all biphasic systems studied in this work, the ionic liquid was the denser phase and no inversion of phases was observed after shaking. The extraction systems were always biphasic.

In this work, the ionic liquid phase is notated as "IL" and hydrochloric acid phase as "aq". The initial and equilibrium concentrations of species in each phase are denoted as "init" and "eq", respectively.

\subsection{NMR measurements}

For all NMR measurements in the present work, solutions of deutero-hydrochloric acid in deuterated water were prepared. The substitution of hydrogen atoms by deuterium in hydrochloric acid and water should not result in a significant change of the studied chemical behavior of these compounds.

The experimental protocol for quantitative fluorine $\left({ }^{19} \mathrm{~F}\right)$ and proton $\left({ }^{1} \mathrm{H}\right)$ nuclear magnetic resonance (NMR) measurements of $\left[\mathrm{C}_{n} \mathrm{mim}\right]\left[\mathrm{Tf}_{2} \mathrm{~N}\right]$ component ions in aqueous nitric acid solutions was described in detail in our previous article. ${ }^{26}$ However, the ${ }^{1} \mathrm{H}$ NMR measurements procedure needed to be adapted for the present study. In the case of $\left[\mathrm{C}_{3} \mathrm{C}_{1}\right.$ pyrr $\left.{ }^{+}\right]$cations, the $\mathrm{CH}_{3}$ group $\left(\delta_{\mathrm{H}} 3.03 \mathrm{ppm}\right)$ and pyrrolidinium ring $\left(\delta_{\mathrm{H}} 2.20 \mathrm{ppm}\right)$ proton signals overlap with sodium citrate $\left(\delta_{\mathrm{H}} 2.4 \mathrm{ppm}\right.$ to 2.8 $\mathrm{ppm}$ ) proton signals, and that can lead to errors in quantitative measurements (see Fig. S1 and Table S1 in the ESI $\dagger$ ). The sodium citrate salt is generally used as an internal standard for $\left[\mathrm{C}_{n} \mathrm{mim}^{+}\right]$cations. ${ }^{26}$ Thus, another internal standard, which provides a good proton resolution, namely maleic acid $\left(\delta_{\mathrm{H}} 6.4\right.$ $\mathrm{ppm})$, was chosen for the determination of $\left[\mathrm{C}_{3} \mathrm{C}_{1} \mathrm{pyrr}^{+}\right]$ concentration in the aqueous DCl solutions. The detection limits for $\left[\mathrm{C}_{n} \mathrm{mim}^{+}\right],\left[\mathrm{C}_{3} \mathrm{C}_{1} \mathrm{pyrr}^{+}\right]$and $\left[\mathrm{Tf}_{2} \mathrm{~N}^{-}\right]$ions were in the

Table 2 The uncertainties of the experimental techniques used in this work

\begin{tabular}{|c|c|c|c|}
\hline Phase & Entity & Technique & Uncertainty, \% \\
\hline \multirow[t]{5}{*}{ Aqueous } & {$\left[\mathrm{H}^{+}\right]$} & Acid-base titration & 2 \\
\hline & {$\left[\mathrm{Cl}^{-}\right]$} & Argentometry & 2 \\
\hline & {$\left[\mathrm{Li}^{+}\right]$} & ICP-AES & 5 \\
\hline & $\begin{array}{l}{\left[\mathrm{C}_{n} \mathrm{mim}^{+}\right],} \\
{\left[\mathrm{C}_{3} \mathrm{C}_{1} \mathrm{pyrr}^{+}\right]}\end{array}$ & Quantitative ${ }^{1} \mathrm{H}$ NMR & 10 \\
\hline & {$\left[\mathrm{Tf}_{2} \mathrm{~N}^{-}\right]$} & Quantitative ${ }^{19} \mathrm{~F}$ NMR & 5 \\
\hline Ionic liquid & $\mathrm{H}_{2} \mathrm{O}$ & Karl-Fisher & 5 \\
\hline
\end{tabular}

range of 1-2 mM. Also, it is known that the longitudinal relaxation time $\left(T_{1}\right)$ depends on the physicochemical properties of the samples such as viscosity, density, mineral acid nature, and ionic strength..$^{39}$ Therefore, $T_{1}$ relaxation times were measured for the aqueous phases prepared by contacting ILs with $\mathrm{D}_{2} \mathrm{O}$ or $10 \mathrm{M} \mathrm{DCl}$. Then, the $T_{1}$ values obtained were applied for all samples characterized in this work in order to provide the optimal analytical conditions for the NMR quantitative measurements in DCl media.

\subsection{Other analytical protocols}

The chloride anion concentration in the aqueous phase was measured by the Mohr method. ${ }^{40}$ The protons' aqueous concentration was determined by acid-base titration (SCHOTT instrument Titroline easy) using $\mathrm{NaOH}$ standard solutions (Carlo Erba). The total water content in the ionic liquid phase was determined by the coulometric Karl-Fisher technique (Hydranal®-Coulomat E, Fluka). The performance of the KarlFisher titrator (Toledo 32 Coulometer) was tested using a standard solution (Hydranal®-Water Standard, Fluka), containing 1000 or $10000 \mathrm{ppm}$ of water. The aqueous lithium ion concentration was measured by an inductively coupled plasma atomic emission spectrometer (ICP-AES, Varian 720ES).

\subsection{Uncertainty of the measurements}

The uncertainties of the experimental techniques used in this work are presented in Table 2.

\section{Results and discussion}

\subsection{Mutual solubility of water and $\mathrm{IL}$ in the presence of $\mathbf{H}\left[\mathbf{T f}_{2} \mathbf{N}\right]$ acid}

First, the simplest case of a liquid-liquid system with a hydrophobic IL and an aqueous acidic phase was explored. The $\mathrm{N}-\mathrm{H}$ acid bis(trifluoromethylsulfonyl)imide, $\mathrm{H}\left[\mathrm{Tf}_{2} \mathrm{~N}\right]$, was used for acidifying the aqueous phase. This acid possesses a common anionic part with the $\left[\mathrm{Tf}_{2} \mathrm{~N}\right]$-based ILs studied in this work. The maximum aqueous concentration of $\mathrm{H}\left[\mathrm{Tf}_{2} \mathrm{~N}\right]$ acid was limited to $2 \mathrm{M}$ because the biphasic system with $\left[\mathrm{C}_{4} \mathrm{mim}\right]\left[\mathrm{Tf}_{2} \mathrm{~N}\right]$ ionic liquid becomes monophasic when $\mathrm{H}\left[\mathrm{Tf}_{2} \mathrm{~N}\right]$ concentration is greater than $3 \mathrm{M}^{27}$

Fig. 2 shows the experimental results on the water solubility in the hydrophobic $\left[\mathrm{C}_{4} \operatorname{mim}\right]\left[\mathrm{Tf}_{2} \mathrm{~N}\right]$ and $\left[\mathrm{C}_{8} \mathrm{mim}\right]\left[\mathrm{Tf}_{2} \mathrm{~N}\right]$ ionic 


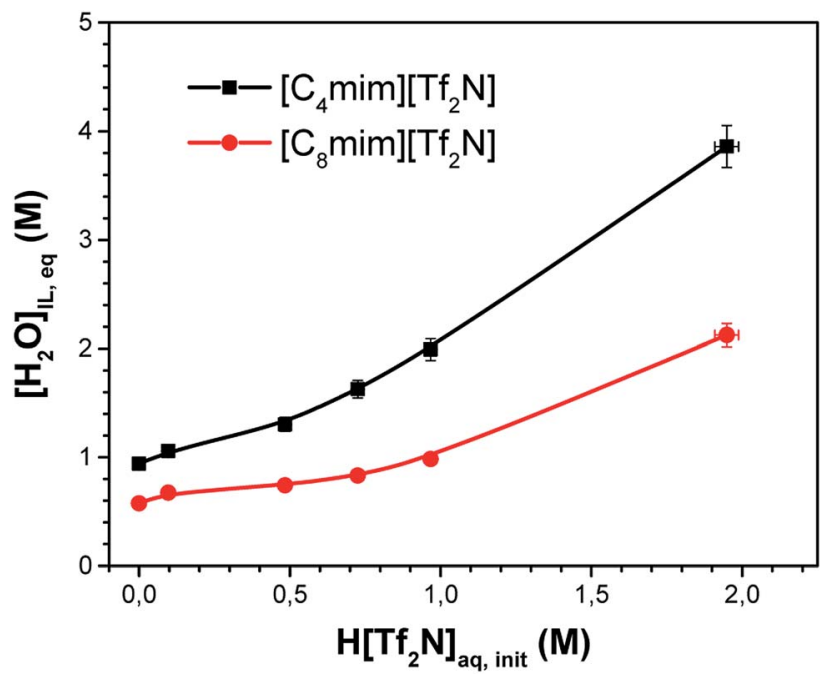

Fig. 2 The effect of aqueous $\mathrm{H}\left[\mathrm{Tf}_{2} \mathrm{~N}\right]$ concentration on the water solubility in the $\left[\mathrm{C}_{4} \mathrm{mim}\right]\left[\mathrm{Tf}_{2} \mathrm{~N}\right]$ and $\left[\mathrm{C}_{8} \mathrm{mim}\right]\left[\mathrm{Tf}_{2} \mathrm{~N}\right]$ ionic liquids. The solid lines are drawn to guide the eye.

liquids as a function of the initial $\mathrm{H}\left[\mathrm{Tf}_{2} \mathrm{~N}\right]$ concentration in the aqueous phase. The equilibrium water amounts in $\left[\mathrm{C}_{4} \mathrm{mim}\right]\left[\mathrm{Tf}_{2} \mathrm{~N}\right]$ and $\left[\mathrm{C}_{8} \mathrm{mim}\right]\left[\mathrm{Tf}_{2} \mathrm{~N}\right]$ when the $\mathrm{H}\left[\mathrm{Tf}_{2} \mathrm{~N}\right]$ concentration is equal to $0 \mathrm{M}$ are 0.94 and $0.58 \mathrm{M}$, respectively. These values are close to those observed in earlier studies (see Table 1). As shown in Fig. 2, the $\mathrm{H}_{2} \mathrm{O}$ equilibrium concentration in $\left[\mathrm{C}_{4} \mathrm{mim}\right]\left[\mathrm{Tf}_{2} \mathrm{~N}\right]$ and $\left[\mathrm{C}_{8} \mathrm{mim}\right]\left[\mathrm{Tf}_{2} \mathrm{~N}\right]$ increases with the introduction of $\mathrm{H}\left[\mathrm{Tf}_{2} \mathrm{~N}\right]$ acid into the aqueous phase.

Fig. 3 shows the equilibrium aqueous concentrations of $\left[\mathrm{C}_{n} \mathrm{mim}^{+}\right](n=4$ and 8$)$ cations as a function of the aqueous $\mathrm{H}\left[\mathrm{Tf}_{2} \mathrm{~N}\right]$ concentration. The addition of $\mathrm{H}\left[\mathrm{Tf}_{2} \mathrm{~N}\right]$ acid up to $c a$. $1 \mathrm{M}$ results in lower aqueous solubilities of IL cations as compared with pure water. On the other hand, the concentration of $\left[\mathrm{C}_{n} \mathrm{mim}^{+}\right](n=4$ and 8) cations rises gradually with increasing concentration of $\mathrm{H}\left[\mathrm{Tf}_{2} \mathrm{~N}\right]$ above $c a$. $0.5 \mathrm{M}$. This

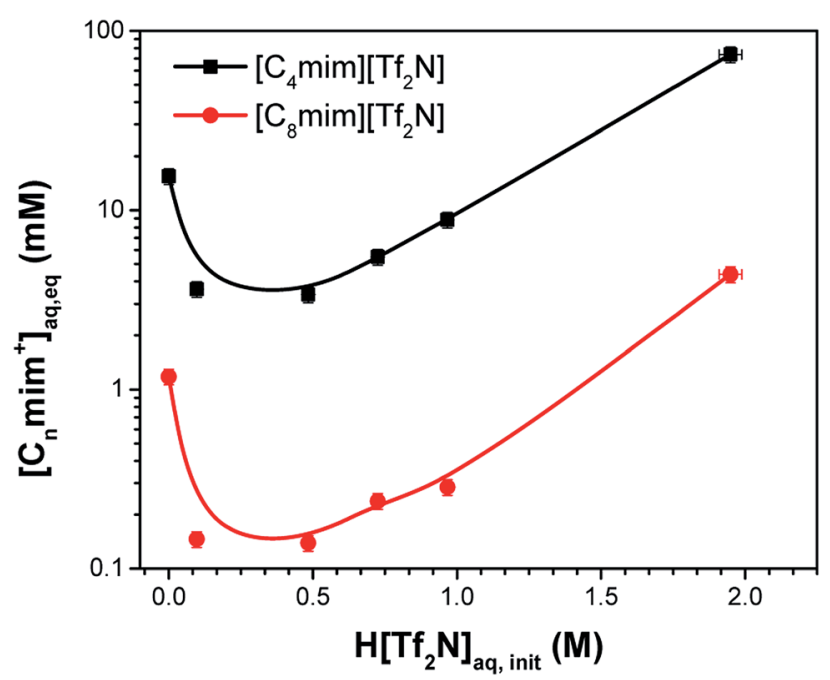

Fig. 3 The effect of the aqueous $H\left[T f_{2} N\right]$ concentration on the equilibrium aqueous concentration of $\left[\mathrm{C}_{n} \mathrm{mim}^{+}\right](n=4$ and 8$)$. The lines are drawn to guide the eye. complex solubility behavior of ILs could be explained by two contradictory effects of the $\mathrm{H}\left[\mathrm{Tf}_{2} \mathrm{~N}\right]$ acid. On the one hand, the dissolving of $\mathrm{H}\left[\mathrm{Tf}_{2} \mathrm{~N}\right]$ (which has the same anion as the IL) in the aqueous phase decreases the aqueous IL solubility in accordance with Le Châtelier's principle. On the other hand, the acid protons tend to lower the interfacial tension and increase the IL solubility in the aqueous phase.

This salting-in effect of acidic protons, i.e., increasing IL solubility, was previously observed for various IL-based biphasic systems in the presence of mineral acids in the aqueous phase. ${ }^{26,27,41}$

In biphasic systems containing water and an IL, the amounts of IL cations and anions passed into the aqueous phase are equal (Fig. 4a). ${ }^{32}$ We suggest that as a result of the contact of the IL phase with the acidic solutions, higher but also equal amounts of IL cations and anions are initially transferred to the aqueous phase (Fig. 4b).

Table 3 shows the change of the $\left[\mathrm{H}^{+}\right]$and $\left[\mathrm{Tf}_{2} \mathrm{~N}^{-}\right]$concentrations in the aqueous phase, i.e., the difference between the added $\mathrm{H}\left[\mathrm{Tf}_{2} \mathrm{~N}\right]$ and the equilibrium aqueous concentrations of $\left[\mathrm{H}^{+}\right]$and $\left[\mathrm{Tf}_{2} \mathrm{~N}^{-}\right]$. It can be seen, the equilibrium concentrations of $\left[\mathrm{H}^{+}\right]$and $\left[\mathrm{Tf}_{2} \mathrm{~N}^{-}\right]$ions are lower than the initial ones when $\mathrm{H}\left[\mathrm{Tf}_{2} \mathrm{~N}\right]$ was added to the aqueous phase. This result can be explained by transfer of some amount of acidic protons and $\left[\mathrm{Tf}_{2} \mathrm{~N}^{-}\right]$anions into the bulk IL phase. The data in Table 3 suggest, especially in the case of $\left[\mathrm{C}_{4} \mathrm{mim}\right]\left[\mathrm{Tf}_{2} \mathrm{~N}\right]$ and for relatively high aqueous concentrations of $\mathrm{H}\left[\mathrm{Tf}_{2} \mathrm{~N}\right]$, that the extraction of $\left[\mathrm{H}^{+}\right]\left[\mathrm{Tf}_{2} \mathrm{~N}^{-}\right]$species occurs in the studied liquid-liquid systems (Fig. 4b):

$$
\mathrm{H}\left[\mathrm{Tf}_{2} \mathrm{~N}\right]_{\mathrm{aq}} \leftrightarrow \mathrm{H}\left[\mathrm{Tf}_{2} \mathrm{~N}\right]_{\mathrm{IL}}
$$

It is evident that the amount of $\mathrm{H}\left[\mathrm{Tf}_{2} \mathrm{~N}\right]$ in associated form increases with the concentration of $\mathrm{H}\left[\mathrm{Tf}_{2} \mathrm{~N}\right]$ acid in the aqueous phase. For instance, $12 \%$ of $\left[\mathrm{Tf}_{2} \mathrm{~N}^{-}\right]$anions are protonated in 0.1 $\mathrm{M} \mathrm{H}\left[\mathrm{Tf}_{2} \mathrm{~N}\right]$, while in $2.11 \mathrm{M} \mathrm{H}\left[\mathrm{Tf}_{2} \mathrm{~N}\right]$ this value is $75 \%$. This issue explains the higher values of $\left[\mathrm{H}^{+}\right]$and $\left[\mathrm{Tf}_{2} \mathrm{~N}^{-}\right]$distributed between the aqueous and IL phases with increasing concentration of $\mathrm{H}\left[\mathrm{Tf}_{2} \mathrm{~N}\right]_{\mathrm{aq} \text {,init }}$ (Table 3).

Finally, we suggest that the water solubility in the imidazolium-based ILs, $\left[\mathrm{C}_{4} \mathrm{mim}\right]\left[\mathrm{Tf}_{2} \mathrm{~N}\right]$ and $\left[\mathrm{C}_{8} \mathrm{mim}\right]\left[\mathrm{Tf}_{2} \mathrm{~N}\right]$, is
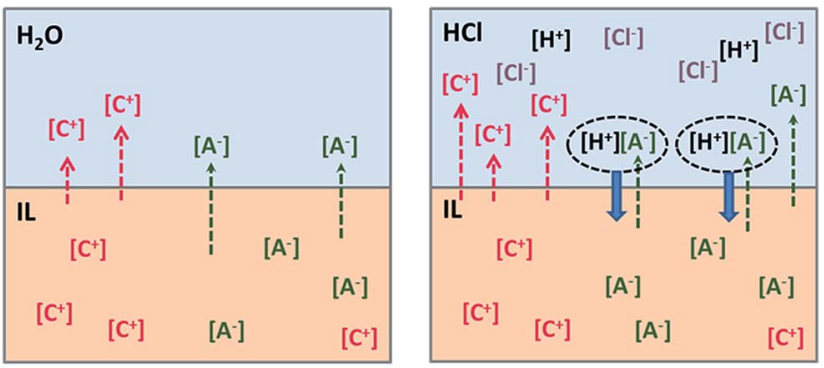

a)

$\left[\mathrm{C}^{+}\right]$- IL cation $\left[\mathrm{A}^{-}\right]-\mathrm{IL}$ anion

b)

Fig. 4 Schematic representation of IL dissolution in pure water (a) and possible mechanism for the dissolution of $\mathrm{IL}$ in the aqueous $\mathrm{HCl}$ solution (b). See the main text for a discussion. 
Table 3 The effect of the aqueous $H\left[\mathrm{Tf}_{2} \mathrm{~N}\right]$ concentration on the equilibrium concentrations of $\left[\mathrm{H}^{+}\right]$and $\left[\mathrm{Tf}_{2} \mathrm{~N}^{-}\right]$in the aqueous phase

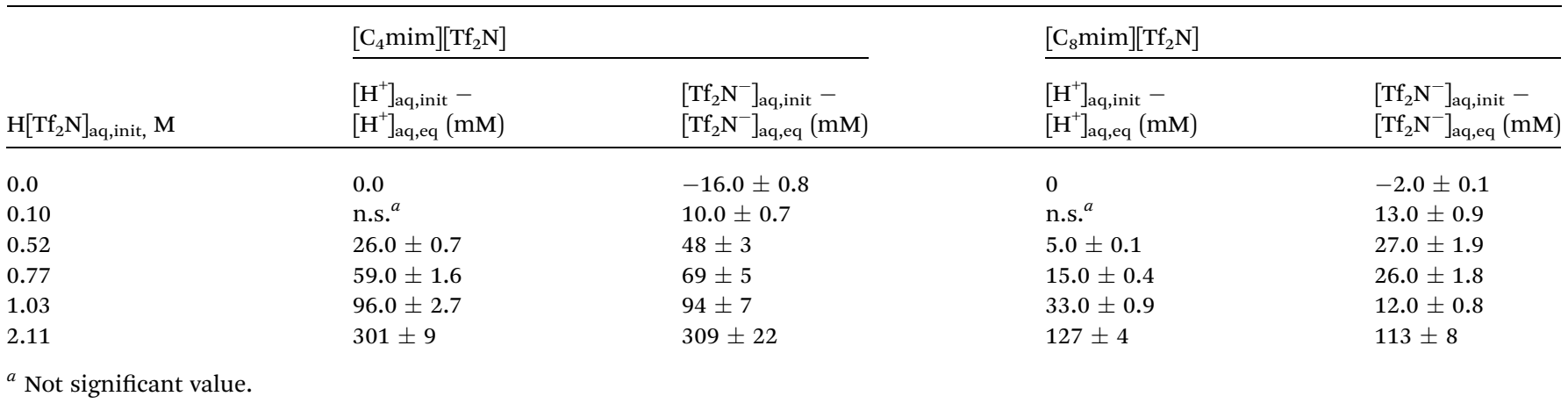

associated with $\mathrm{H}\left[\mathrm{Tf}_{2} \mathrm{~N}\right]$ formed in the aqueous phase and then extracted into the IL phase. It is well known that the extraction of acid is accompanied by extraction of water in traditional solvent extraction. ${ }^{42}$ Moreover, Katase et $a .^{\mathbf{4 3}}$ showed that the presence of $\mathrm{H}\left[\mathrm{Tf}_{2} \mathrm{~N}\right]$ in the hydrophobic IL, trimethyl- $n$-hexylammonium bis(trifluoromethylsulfonyl)amide, leads to a significant rise of water content absorbed from the ambient air as compared with neat IL. Besides, Stoyanov et al. ${ }^{\mathbf{4 4}}$ reported that $\mathrm{H}\left[\mathrm{Tf}_{2} \mathrm{~N}\right]$ forms mono- and dihydrated species, $\left(\mathrm{CF}_{3} \mathrm{SO}_{2}\right)_{2} \mathrm{NH} \cdot \mathrm{H}_{2} \mathrm{O}$ and $\left(\mathrm{CF}_{3} \mathrm{SO}_{2}\right)_{2} \mathrm{NH} \cdot\left(\mathrm{H}_{2} \mathrm{O}\right)_{2}$ in organic solvents, such as 1,2-dichloroethane, benzene and tetrachloride. Therefore, the water uptake in ILs from the aqueous acidic phase is probably proportional to the amount of extracted hydrated $\mathrm{H}\left[\mathrm{Tf}_{2} \mathrm{~N}\right]$.

\subsection{Mutual solubility of water and IL in the presence of $\mathrm{HCl}$ acid}

The IL-based biphasic system in the presence of hydrochloric acid in the aqueous phase is considered in this section.

The experimental data on the solubility of water in $\left[\mathrm{C}_{n} \mathrm{mim}\right]\left[\mathrm{Tf}_{2} \mathrm{~N}\right](n=2,4,6$ or 8$)$ and $\left[\mathrm{C}_{3} \mathrm{C}_{1}\right.$ pyrr $]\left[\mathrm{Tf}_{2} \mathrm{~N}\right]$ ionic liquids as a function of the initial aqueous hydrochloric acid concentration $\left([\mathrm{DCl}]_{\mathrm{aq}, \text { init }}\right)$ are shown in Fig. 5 .

Our experimental data on the water solubility in $\left[\mathrm{C}_{n} \mathrm{mim}\right]\left[\mathrm{Tf}_{2} \mathrm{~N}\right](n=2-8)$ equilibrated with pure water and in $\left[\mathrm{C}_{4} \mathrm{mim}\right]\left[\mathrm{Tf}_{2} \mathrm{~N}\right]$ equilibrated with $\mathrm{HCl}$ solutions are in agreement with those obtained previously. ${ }^{45,46}$ It is interesting to note that the addition of $\mathrm{HCl}$ acid to the aqueous phase results in lower water content in $\left[\mathrm{C}_{n} \mathrm{mim}\right]\left[\mathrm{Tf}_{2} \mathrm{~N}\right](n=4$ and 8$)$ as compared to $\mathrm{H}\left[\mathrm{Tf}_{2} \mathrm{~N}\right]$ acid.

As shown in Fig. 5, the water solubility in the studied set of $\left[\mathrm{Tf}_{2} \mathrm{~N}^{-}\right]$-based ILs at a given DCl concentration decreases in order $\left[\mathrm{C}_{2} \mathrm{mim}\right]\left[\mathrm{Tf}_{2} \mathrm{~N}\right]>\left[\mathrm{C}_{3} \mathrm{C}_{1}\right.$ pyrr $]\left[\mathrm{Tf}_{2} \mathrm{~N}\right]>\left[\mathrm{C}_{4} \mathrm{mim}\right]\left[\mathrm{Tf}_{2} \mathrm{~N}\right]>$ $\left[\mathrm{C}_{6} \mathrm{mim}\right]\left[\mathrm{Tf}_{2} \mathrm{~N}\right]>\left[\mathrm{C}_{8} \mathrm{mim}\right]\left[\mathrm{Tf}_{2} \mathrm{~N}\right]$. This trend evidently correlates with the hydrophobicity of the studied ILs (Table 1). For the $\left[\mathrm{C}_{n} \mathrm{mim}\right]\left[\mathrm{Tf}_{2} \mathrm{~N}\right]$ ionic liquids, it is known that their hydrophobicity increases with elongation of the cation alkyl chain. ${ }^{31}$ So, the water uptake into $\left[\mathrm{C}_{2} \mathrm{mim}\right]\left[\mathrm{Tf}_{2} \mathrm{~N}\right]$ equilibrated with $7.1 \mathrm{M}$ $\mathrm{DCl}$ is $2.2 \mathrm{M}$, which decreases to $1.0 \mathrm{M}$ into $\left[\mathrm{C}_{4} \mathrm{mim}\right]\left[\mathrm{Tf}_{2} \mathrm{~N}\right]$, to $0.48 \mathrm{M}$ into $\left[\mathrm{C}_{6} \mathrm{mim}\right]\left[\mathrm{Tf}_{2} \mathrm{~N}\right]$, and to $0.32 \mathrm{M}$ into $\left[\mathrm{C}_{8} \mathrm{mim}\right]\left[\mathrm{Tf}_{2} \mathrm{~N}\right]$, while the $\left[\mathrm{C}_{n} \mathrm{mim}^{+}\right]$hydrophobicities are $0.22,0.67,1.2$, and 1.9, respectively, for $n=2,4,6$ or $8 .{ }^{31}$ The same decreasing trend of

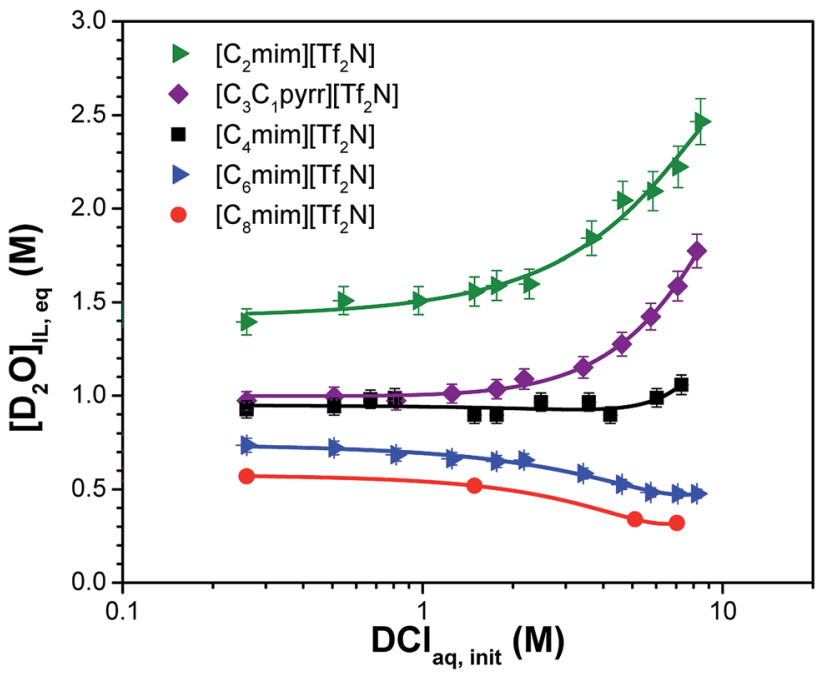

Fig. 5 Equilibrium $\mathrm{D}_{2} \mathrm{O}$ content in $\left[\mathrm{C}_{n} \operatorname{mim}\right]\left[\mathrm{Tf}_{2} \mathrm{~N}\right](n=2,4,6$, and 8) and $\left[\mathrm{C}_{3} \mathrm{C}_{1}\right.$ pyrr] $\left[\mathrm{Tf}_{2} \mathrm{~N}\right]$ ionic liquids as a function of initial aqueous $\mathrm{DCl}$ concentration. The solid lines are drawn to guide the eye.

water solubility with increasing of alkyl chain length was observed in previous studies on the biphasic systems composed of dialkylimidazolium-based ILs $\left[\mathrm{C}_{n} \operatorname{mim}\right]\left[\mathrm{Tf}_{2} \mathrm{~N}\right](n=2-8)$ and water, ${ }^{34,44-46}\left[\mathrm{C}_{n} \mathrm{mim}\right]\left[\mathrm{PF}_{6}\right](n=4,6,8)$ and water, ${ }^{37}\left[\mathrm{C}_{n} \mathrm{mim}\right]$ $\left[\mathrm{Tf}_{2} \mathrm{~N}\right](n=2,4,6,8,10)$ and $\mathrm{DCl}(\mathrm{pH}=0.5-7),{ }^{35}\left[\mathrm{C}_{n} \mathrm{mim}\right]\left[\mathrm{Tf}_{2} \mathrm{~N}\right]$ ( $n=4$ and 10) and $\mathrm{HNO}_{3} \cdot{ }^{47}$

From the data in Fig. 5, it is apparent that the increase of aqueous DCl concentration leads to the continual and significant rise of equilibrium water content in $\left[\mathrm{C}_{2} \mathrm{mim}\right]\left[\mathrm{Tf}_{2} \mathrm{~N}\right]$ and $\left[\mathrm{C}_{3} \mathrm{C}_{1}\right.$ pyrr $]\left[\mathrm{Tf}_{2} \mathrm{~N}\right]$, while it remains almost constant in the $\left[\mathrm{C}_{4} \mathrm{mim}\right]\left[\mathrm{Tf}_{2} \mathrm{~N}\right]$ ionic liquid. Surprisingly, the presence of $0-8 \mathrm{M}$ $\mathrm{DCl}$ in the aqueous phase results in a slight decline of equilibrium $\mathrm{H}_{2} \mathrm{O}$ concentration in $\left[\mathrm{C}_{6} \mathrm{mim}\right]\left[\mathrm{Tf}_{2} \mathrm{~N}\right]$ and $\left[\mathrm{C}_{8} \mathrm{mim}\right]\left[\mathrm{Tf}_{2} \mathrm{~N}\right]$. These findings indicate that the effect of $\mathrm{HCl}$ acid on the water solubility in $\left[\mathrm{C}_{n} \mathrm{mim}\right]\left[\mathrm{Tf}_{2} \mathrm{~N}\right]$ differs from that of $\mathrm{HNO}_{3}$. Our previous study has showed that the presence of nitric acid increases the water content in $\left[\mathrm{C}_{4} \mathrm{mim}\right]\left[\mathrm{Tf}_{2} \mathrm{~N}\right]$ and in $\left[\mathrm{C}_{10} \mathrm{mim}\right]\left[\mathrm{Tf}_{2} \mathrm{~N}\right]$ ionic liquids. ${ }^{47}$

The increase of the water content in ILs contacted with aqueous DCl solutions is probably caused by the extraction of hydrated $\mathrm{H}\left[\mathrm{Tf}_{2} \mathrm{~N}\right]$ species as previously discussed for IL-based 
biphasic systems with aqueous $\mathrm{H}\left[\mathrm{Tf}_{2} \mathrm{~N}\right]$ solutions (Fig. 4b). However, the effect of DCl presence on the water solubility in long alkyl chain ILs ( $n=6$ and 8), is not fully understood yet.

Fig. 6 shows the dependency of the equilibrium water content as a function of the number of carbon atoms on the longer alkyl side chain of the cation at different aqueous DCl concentrations for the set of $\left[\mathrm{C}_{n} \operatorname{mim}\right]\left[\mathrm{Tf}_{2} \mathrm{~N}\right](n=2,4,6$ or 8$)$ ionic liquids. There is a monotonic water solubility decrease with an increase in the alkyl chain length. However, the water uptake in $\left[\mathrm{C}_{6} \mathrm{mim}\right]\left[\mathrm{Tf}_{2} \mathrm{~N}\right]$ and $\left[\mathrm{C}_{8} \mathrm{mim}\right]\left[\mathrm{Tf}_{2} \mathrm{~N}\right]$ shows a weaker dependence on the alkyl side chain length than in $\left[\mathrm{C}_{2} \mathrm{mim}\right]\left[\mathrm{Tf}_{2} \mathrm{~N}\right]$ and $\left[\mathrm{C}_{4} \mathrm{mim}\right]\left[\mathrm{Tf}_{2} \mathrm{~N}\right]$. The inflection point is located at $n \approx 4-5$. It is interesting to note that other properties of $\left[\mathrm{C}_{n} \mathrm{mim}\right]\left[\mathrm{Tf}_{2} \mathrm{~N}\right]$ ionic liquids $(n=2-10)$, such as interfacial tension, viscosity, and density, as well as water uptake and various thermophysical parameters, are reported to be dependent on alkyl chain length with an inflection point of $n \approx 6 .{ }^{35} \mathrm{In}$ the literature, this point is called the critical alkyl chain length (CAL) and is found to be related to the structural segregation in the liquid. ${ }^{48}$ It is recognized that ionic liquids display mesostructural ordering with segregated regions of polar and nonpolar domains formed by the alkyl chains of the cations. ${ }^{49,50}$ The IL ions interact with water due to ion-dipole forces. ${ }^{51}$ The higher affinity of short alkyl chains of imidazolium-based ILs ( $n=2$ and 4 ) towards water is probably caused by higher polarity, ${ }^{52}$ that leads to stronger water and ionic liquid interactions. Recently, quantum chemical density functional theory calculations have shown that water is solvated preferentially on the IL polar region, namely on the aromatic head and adjacent methylene groups. ${ }^{53}$ For $\left[\mathrm{C}_{n} \mathrm{mim}\right]\left[\mathrm{Tf}_{2} \mathrm{~N}\right]$ ionic liquids with $n=2$ and 4 , i.e., lower than $\mathrm{CAL}$, the elongation of the alkyl side chain strongly affects the charge distribution of the cations, and explains the stronger dependency of the water uptake. The molecular dynamics study of the $\left[\mathrm{C}_{n} \mathrm{mim}\right]\left[\mathrm{Tf}_{2} \mathrm{~N}\right]$ homolog series $(n=2-10)$

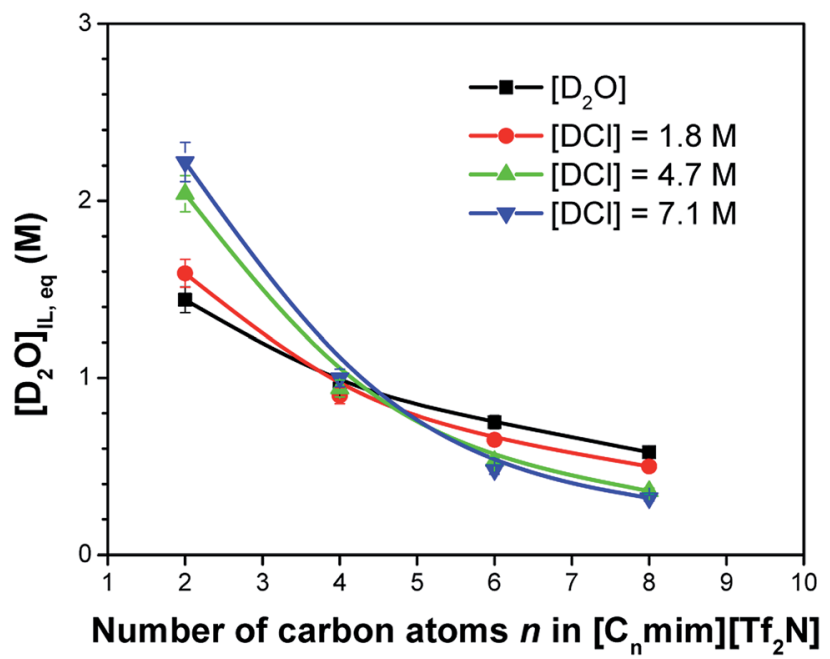

Fig. 6 Equilibrium $\mathrm{D}_{2} \mathrm{O}$ content in imidazolium-based ILs, $\left[\mathrm{C}_{n} \operatorname{mim}\right]\left[\mathrm{Tf}_{2} \mathrm{~N}\right](n=2,4,6$, and 8$)$, contacted with water and aqueous $\mathrm{DCl}$ solutions as a function of the number of carbon atoms on the longer alkyl chain, $n$. The solid lines are drawn to guide the eye. showed that the nonpolar aggregates in $\left[\mathrm{C}_{2} \operatorname{mim}\right]\left[\mathrm{Tf}_{2} \mathrm{~N}\right]$ and $\left[\mathrm{C}_{4} \mathrm{mim}\right]\left[\mathrm{Tf}_{2} \mathrm{~N}\right]$ form clusters and start to percolate the IL as a continuous nonpolar subphase for $n \geq 6 .{ }^{50}$ Small-wide angle $\mathrm{X}$-ray scattering measurements of the $\left[\mathrm{C}_{n} \mathrm{mim}\right]\left[\mathrm{Tf}_{2} \mathrm{~N}\right]$ ionic liquids $(n=2-12)$ provide further support for this theory. ${ }^{48}$ Thus, the smoothed change of the water solubility in ILs with $n$ $>$ CAL could be explained by a less pronounced change in the charge distribution associated with the more separated strands of the polar network. ${ }^{50}$

The transfer of hydrochloric acid from the aqueous phase into the ILs $\left[\mathrm{C}_{n} \mathrm{mim}\right]\left[\mathrm{Tf}_{2} \mathrm{~N}\right](n=2,4,6$, and 8) and $\left[\mathrm{C}_{3} \mathrm{C}_{1}\right.$ pyrr $]\left[\mathrm{Tf}_{2} \mathrm{~N}\right]$ has been studied. Fig. 7 shows the difference between initial and equilibrium concentration of $\left[\mathrm{D}^{+}\right]$ions, i.e., the amount of $\left[\mathrm{D}^{+}\right]$transferred into the organic phase, as a function of the initial aqueous DCl concentration.

It can be seen the transfer of acidic protons from the aqueous to IL phase is evident for $\left[\mathrm{C}_{2} \mathrm{mim}\right]\left[\mathrm{Tf}_{2} \mathrm{~N}\right],\left[\mathrm{C}_{3} \mathrm{C}_{1}\right.$ pyrr $]\left[\mathrm{Tf}_{2} \mathrm{~N}\right]$ and $\left[\mathrm{C}_{4} \mathrm{mim}\right]\left[\mathrm{Tf}_{2} \mathrm{~N}\right]$ ionic liquids. Unfortunately, the variation of $\left[\mathrm{D}^{+}\right]$ for $\left[\mathrm{C}_{6} \mathrm{mim}\right]\left[\mathrm{Tf}_{2} \mathrm{~N}\right]$ and $\left[\mathrm{C}_{8} \mathrm{mim}\right]\left[\mathrm{Tf}_{2} \mathrm{~N}\right]$ are within uncertainty measurements.

The chloride anions were not detectably extracted into the studied ILs from the aqueous DCl solutions. Chloride anions are small ions with high charge density that results in their high solvation by water molecules and highly hydrophilic behavior. Thus, ILs with hydrophobic anions such as $\left[\mathrm{Tf}_{2} \mathrm{~N}^{-}\right]$are reported to be very difficult to exchange with chloride anions. No chloride ion transfer from the aqueous solutions was previously reported into the $\left[\mathrm{C}_{4} \mathrm{mim}\right]\left[\mathrm{Tf}_{2} \mathrm{~N}\right],{ }^{27}\left[\mathrm{P}_{66614}\right]\left[\mathrm{Tf}_{2} \mathrm{~N}\right],{ }^{41}$ and $[$ Hbet $]\left[\mathrm{Tf}_{2} \mathrm{~N}\right]^{54}$ ionic liquids.

It is known that hydrophobic imidazolium-based ILs are slightly soluble in water, but the presence of mineral acids in the aqueous phase results in a significant loss of IL constituent ions. ${ }^{26,27}$ In the current work, the effect of hydrochloric acid concentration has been studied for the $\left[\mathrm{C}_{n} \operatorname{mim}\right]\left[\mathrm{Tf}_{2} \mathrm{~N}\right](n=2,4$, 6 , and 8 ) and $\left[\mathrm{C}_{3} \mathrm{C}_{1}\right.$ pyrr $]\left[\mathrm{Tf}_{2} \mathrm{~N}\right]$ ionic liquids. Fig. 8 shows the

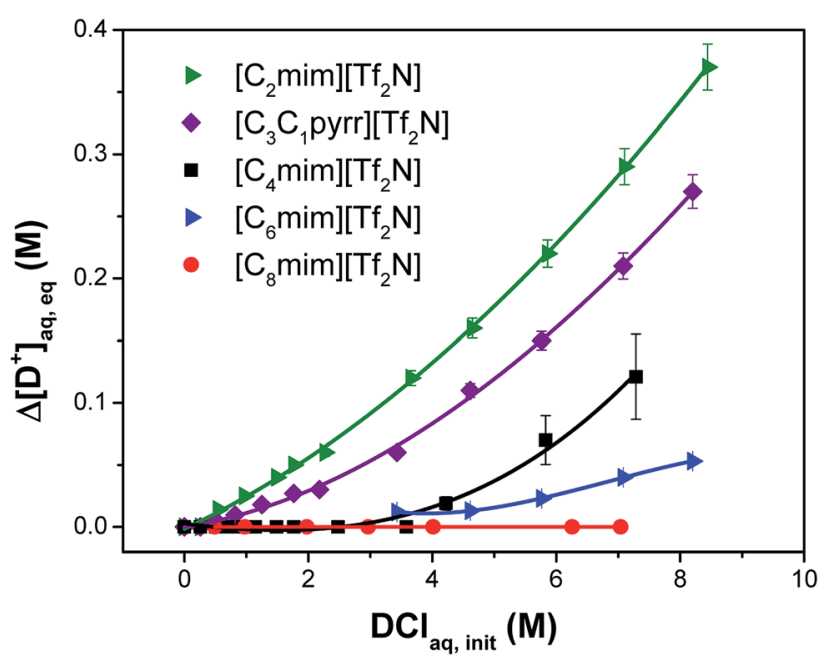

Fig. 7 The change in equilibrium $\left[\mathrm{D}^{+}\right]$concentrations in the aqueous phase, i.e., the amount of $\left[\mathrm{D}^{+}\right]$transferred into the organic phase, as a function of initial aqueous $\mathrm{DCl}$ concentration. The solid lines are drawn to guide the eye. 

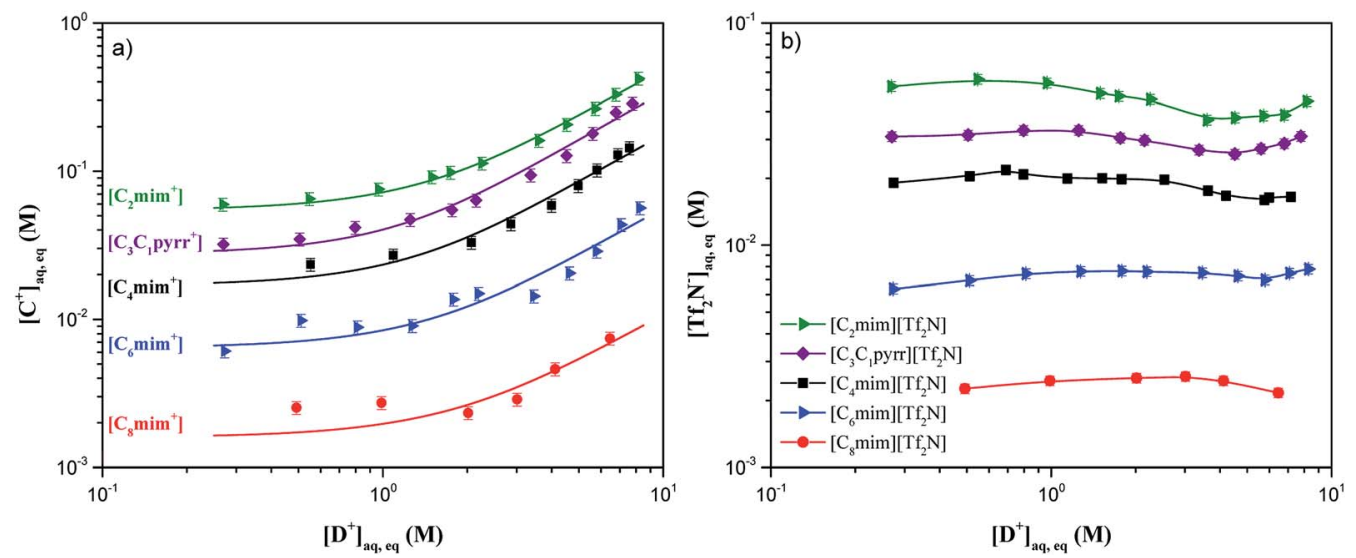

Fig. 8 Effect of the hydrochloric acid concentration on the solubility of different $\mathrm{Tf}_{2} \mathrm{~N}$-based ILs in the aqueous phase: (a) IL cation; (b) IL anion. The solid lines are drawn to guide the eye.

variation of the IL constituent ions' concentration in the aqueous phase as a function of the initial hydrochloric acid concentration.

As can be seen, the equilibrium concentrations of the IL component cations at a given $\mathrm{HCl}$ concentration decrease in the order $\left[\mathrm{C}_{2} \mathrm{mim}^{+}\right]>\left[\mathrm{C}_{3} \mathrm{C}_{1} \mathrm{pyrr}^{+}\right]>\left[\mathrm{C}_{4} \mathrm{mim}^{+}\right]>\left[\mathrm{C}_{6} \mathrm{mim}^{+}\right]>\left[\mathrm{C}_{8} \mathrm{mim}^{+}\right]$. The same order was observed for the solubility of water in the studied ILs (Fig. 5). For all $\left[\mathrm{Tf}_{2} \mathrm{~N}^{-}\right]$-based ILs, the amount of the IL cations in the aqueous phase increases with increasing $[\mathrm{DCl}]_{\mathrm{aq} \text {,init }}$ (Fig. 8a) as was previously observed for $\mathrm{H}\left[\mathrm{Tf}_{2} \mathrm{~N}\right]$ in the aqueous phase (see Fig. 3). The variation of $\left[\mathrm{Tf}_{2} \mathrm{~N}^{-}\right]$anion concentrations is much less pronounced and seems to be non-monotonic.

A study of the $\left[\mathrm{C}_{4} \mathrm{mim}\right]\left[\mathrm{Tf}_{2} \mathrm{~N}\right]$ solubility in aqueous solutions of nitric acid showed that both the IL cation and anion content in the aqueous phase increase as a function of $\mathrm{DNO}_{3}$ concentration. ${ }^{41}\left[\mathrm{C}_{4} \mathrm{mim}^{+}\right]$and $\left[\mathrm{Tf}_{2} \mathrm{~N}^{-}\right]$concentrations changed from approximately $15 \mathrm{mM}$ in pure water to approximately $90 \mathrm{mM}$ in $\left[\mathrm{DNO}_{3}\right]_{\mathrm{aq}, \text { init }}=6 \mathrm{M}$. The concentration of the $\left[\mathrm{C}_{4} \mathrm{mim}^{+}\right]$cation was previously found to be $293 \mathrm{mM}$ when $\left[\mathrm{C}_{4} \mathrm{mim}\right]\left[\mathrm{Tf}_{2} \mathrm{~N}\right]$ was in contact with $5.9 \mathrm{M} \mathrm{HClO}_{4}$, but no $\left[\mathrm{Tf}_{2} \mathrm{~N}^{-}\right]$solubility was reported. ${ }^{27}$ In this study, in $[\mathrm{HCl}]_{\mathrm{aq}, \text { init }}=6 \mathrm{M}$, the amounts of $\mathrm{IL}$ cationic and anionic components for $\left[\mathrm{C}_{4} \mathrm{mim}\right]\left[\mathrm{Tf}_{2} \mathrm{~N}\right]$ are approximately 91 and $16 \mathrm{mM}$, respectively. The lower concentrations of $\left[\mathrm{Tf}_{2} \mathrm{~N}^{-}\right]$anions than corresponding IL cations can be explained by the extraction of $\mathrm{H}\left[\mathrm{Tf}_{2} \mathrm{~N}\right]$ from the aqueous phase into the IL phase (Fig. 4). The higher aqueous solubility of the $\left[\mathrm{C}_{4} \mathrm{mim}\right]\left[\mathrm{T}_{2} \mathrm{~N}\right]$ ionic liquid in nitric and perchloric acid solutions is probably caused by higher efficiency of anion exchange between $\left[\mathrm{Tf}_{2} \mathrm{~N}^{-}\right]$and the acid counterions. It is evident that the observed salting-in effect (i.e., the increase of IL aqueous solubility) of these mineral acids followed the rank order $\mathrm{HClO}_{4}>$ $\mathrm{HNO}_{3}>\mathrm{HCl}$, corresponding to the Hofmeister series. The same trend was reported for the aqueous solubility of betainium and choline bis(trifluorosulfonyl)imide ILs, [Hbet][ $\left.\mathrm{Tf}_{2} \mathrm{~N}\right]$ and [Chol] [ $\left.\mathrm{Tf}_{2} \mathrm{~N}\right]$, contacted with $1 \mathrm{M} \mathrm{HClO}_{4}, \mathrm{HNO}_{3}$, and $\mathrm{HCl}$ solutions. $^{55}$ The possible equilibria in the biphasic system composed of IL and hydrochloric acid solutions is discussed below.

\subsection{Mutual solubility of water and $\mathrm{IL}$ in the presence of $\mathrm{Li}\left[\mathrm{Tf}_{2} \mathrm{~N}\right],\left[\mathrm{C}_{4} \mathbf{m i m}\right] \mathrm{Cl}$ and $\mathrm{HCl}$}

The presence of various acids in the aqueous phase is not the only factor that can affect the mutual solubility of water and ILs. Some metal and organic salts, such as $\mathrm{NaNO}_{3}, \mathrm{NaCl}, \mathrm{Li}\left[\mathrm{Tf}_{2} \mathrm{~N}\right]$, $\left[\mathrm{C}_{n} \mathrm{mim}\right] \mathrm{Cl}$, etc., are also known to be able to considerably modify the properties of biphasic systems with ILs. ${ }^{35,41,56}$ The effect of the salts $\left[\mathrm{C}_{4} \mathrm{mim}\right] \mathrm{Cl}$ and $\mathrm{Li}\left[\mathrm{Tf}_{2} \mathrm{~N}\right]$, containing common cationic or anionic parts with the $\left[\mathrm{C}_{4} \mathrm{mim}\right]\left[\mathrm{Tf}_{2} \mathrm{~N}\right]$ ionic liquid, was investigated in this work because the introduction of these compounds in the aqueous acidic phase is widely used for understanding the extraction mechanism of metallic ions in ILbased biphasic systems. ${ }^{2,29,57}$

Fig. 9 shows the experimental results on the solubility of water in the $\left[\mathrm{C}_{4} \mathrm{mim}\right]\left[\mathrm{Tf}_{2} \mathrm{~N}\right]$ ionic liquid that was contacted with an aqueous hydrochloric acid solution $\left([\mathrm{HCl}]_{\mathrm{aq}, \text { init }}=1.1\right.$ or $\left.5.7 \mathrm{M}\right)$ with various amounts of dissolved $\left[\mathrm{C}_{4} \mathrm{mim}\right] \mathrm{Cl}$ or $\mathrm{Li}\left[\mathrm{Tf}_{2} \mathrm{~N}\right]$ salts.

These two salts have opposing influences on the water content in the $\left[\mathrm{C}_{4} \mathrm{mim}\right]\left[\mathrm{Tf}_{2} \mathrm{~N}\right]$ ionic liquid. The introduction of $\left[\mathrm{C}_{4} \mathrm{mim}\right] \mathrm{Cl}$ in $\mathrm{HCl}$ solutions leads to a slight decrease in water content in the $\mathrm{IL}$, while the presence of $\mathrm{Li}\left[\mathrm{Tf}_{2} \mathrm{~N}\right]$ noticeably increases water solubility. The effect of $\mathrm{Li}\left[\mathrm{Tf}_{2} \mathrm{~N}\right]$ and $\left[\mathrm{C}_{4} \mathrm{mim}\right] \mathrm{Cl}$ salts dissolved in the aqueous acidic phase on the water uptake in ILs is more pronounced at higher aqueous $\mathrm{HCl}$ concentrations. These results will be discussed below.

The effect of common anion introduced in excess in the aqueous $\mathrm{HCl}$ phase (as a $\mathrm{Li}\left[\mathrm{Tf}_{2} \mathrm{~N}\right]$ salt) on the solubility of the $\left[\mathrm{C}_{4} \mathrm{mim}\right]\left[\mathrm{Tf}_{2} \mathrm{~N}\right]$ ionic liquid in water was also investigated (Fig. 10). No detectable $\mathrm{Li}^{+}$transfer into the IL phase was observed. As can be seen in $\mathrm{HCl}$ solutions, the equilibrium aqueous concentrations of the $\left[\mathrm{Tf}_{2} \mathrm{~N}^{-}\right]$anion are lower than the initial ones. This result indicates that a fraction of the $\left[\mathrm{Tf}_{2} \mathrm{~N}^{-}\right]$ anions was transferred from the aqueous phase into the IL, probably in the protonated form $\mathrm{H}\left[\mathrm{Tf}_{2} \mathrm{~N}\right]$. On the other hand, the aqueous solubility of IL cations is reduced, i.e., the saltingout effect is observed. It should be noted that, analogous with water solubility in $\left[\mathrm{C}_{4} \mathrm{mim}\right]\left[\mathrm{Tf}_{2} \mathrm{~N}\right]$, the solubility of the IL in the aqueous phase with added $\operatorname{Li}\left[\mathrm{Tf}_{2} \mathrm{~N}\right]$ is more pronounced at 

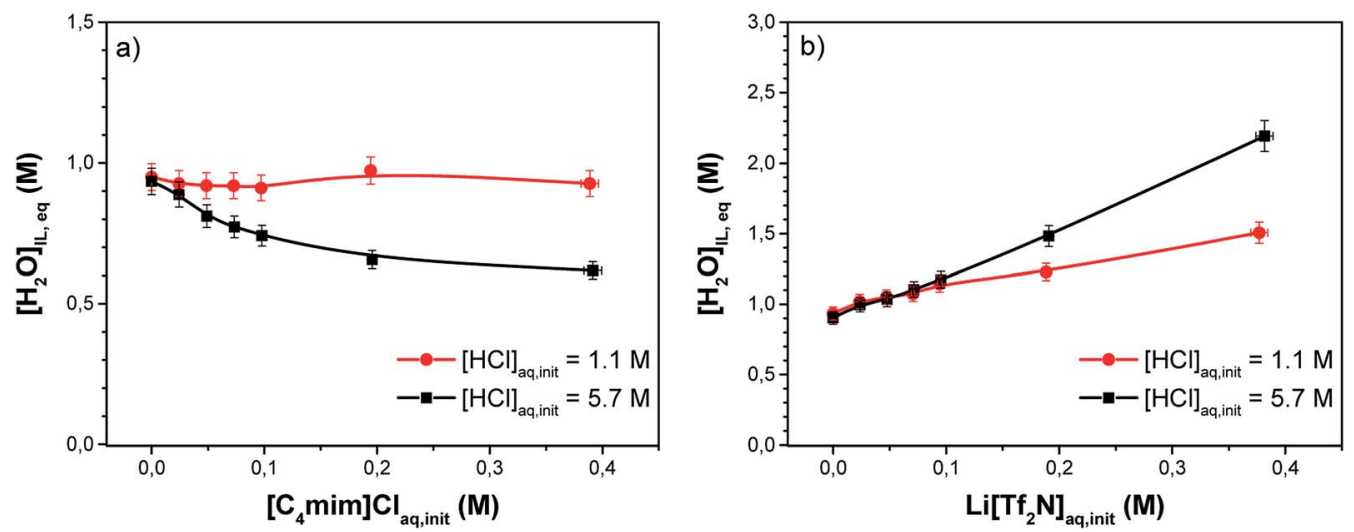

Fig. 9 Equilibrium water content in $\left[\mathrm{C}_{4} \mathrm{mim}\right]\left[\mathrm{Tf}_{2} \mathrm{~N}\right]$ ionic liquid as a function of the salt concentration in the aqueous hydrochloric acid solution $([\mathrm{HCl}]=1.1$ or $5.7 \mathrm{M})$ : (a) $\left[\mathrm{C}_{4} \mathrm{mim}\right] \mathrm{Cl} ;(\mathrm{b}) \mathrm{Li}\left[\mathrm{Tf}_{2} \mathrm{~N}\right]$. The lines are drawn to guide the eye.
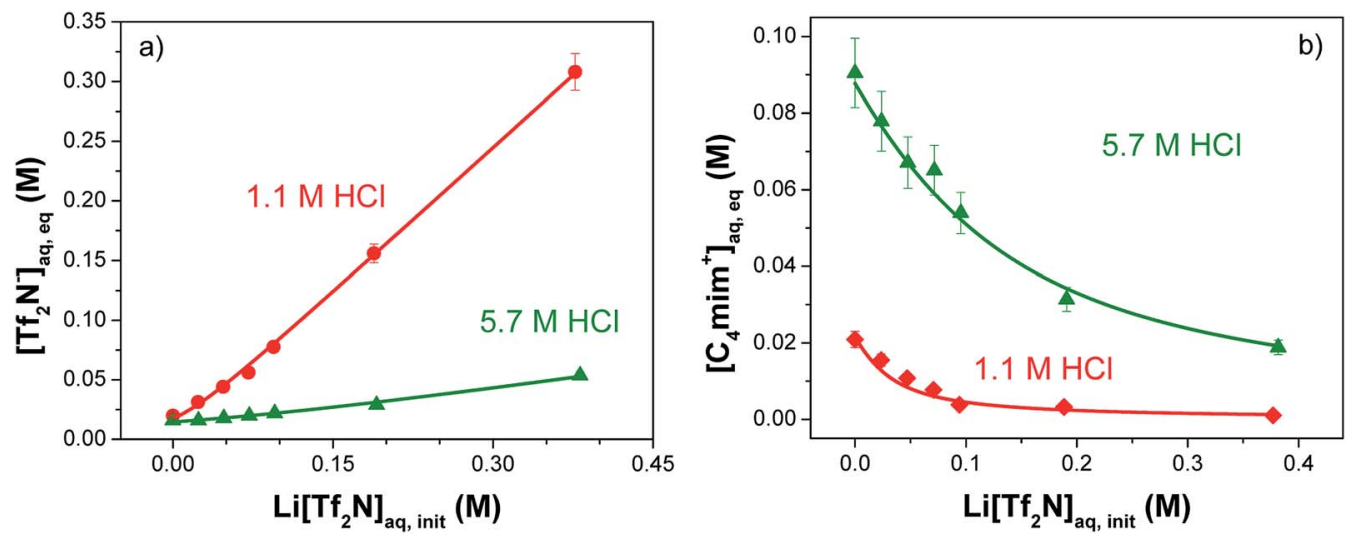

Fig. 10 The equilibrium concentration of $\left[\mathrm{Tf}_{2} \mathrm{~N}^{-}\right](\mathrm{a})$ and $\left[\mathrm{C}_{4} \mathrm{mim}^{+}\right]$(b) in aqueous hydrochloric acid solutions as a function of added Li[Tf $\mathrm{N}_{2} \mathrm{~N}$ concentration according to eqn (12) and (13) below.

higher acidity. This result can be also explained by the formation and extraction of hydrated $\mathrm{H}\left[\mathrm{Tf}_{2} \mathrm{~N}\right]$ from $\mathrm{HCl}$ media into the IL phase. As was discussed above, the ionic liquid anions, $\left[\mathrm{Tf}_{2} \mathrm{~N}^{-}\right]$, are partially protonated in the acidic solutions and the fraction of $\mathrm{H}\left[\mathrm{Tf}_{2} \mathrm{~N}\right]$ is higher at higher $\mathrm{HCl}$ concentrations.

Fig. 11 shows the equilibrium concentrations of $\left[\mathrm{C}_{4} \mathrm{mim}^{+}\right]$ and $\left[\mathrm{Tf}_{2} \mathrm{~N}^{-}\right]$ions after contacting $\left[\mathrm{C}_{4} \mathrm{mim}\right]\left[\mathrm{Tf}_{2} \mathrm{~N}\right]$ ionic liquid with hydrochloric acid solutions containing various amounts of $\left[\mathrm{C}_{4} \mathrm{mim}\right] \mathrm{Cl}$ salt. The introduction of the salt with a common cationic part results in a decrease of IL solubility because the equilibrium aqueous concentration of cations is lower than the sum of introduced $\left[\mathrm{C}_{4} \mathrm{mim}\right] \mathrm{Cl}$ concentration and IL cation solubility for a given acidity in the absence of salt, i.e., the concentrations of aqueous initial and equilibrium $\left[\mathrm{C}_{4} \mathrm{mim}^{+}\right]$are almost equal. The $\left[\mathrm{Tf}_{2} \mathrm{~N}^{-}\right]$amount also decreases with increasing $\left[\mathrm{C}_{4} \mathrm{mim}\right] \mathrm{Cl}$ addition. The acid protons were not detectably extracted into the IL phase under these experimental conditions. As can be seen, the acidity of the aqueous phase slightly affects the observed IL solubility behavior.

The decreasing aqueous solubility of $\left[\mathrm{C}_{4} \mathrm{mim}^{+}\right]$and $\left[\mathrm{Tf}_{2} \mathrm{~N}^{-}\right]$ ions in the case when $\mathrm{Li}\left[\mathrm{Tf}_{2} \mathrm{~N}\right]$ or $\left[\mathrm{C}_{4} \mathrm{mim}\right] \mathrm{Cl}$, respectively, were added to the aqueous phase (Fig. 10b and 11b) is in agreement with Le Châtelier's principle. In fact, the addition of these salts shifts the equilibrium reaction to the side of $\left[\mathrm{C}_{4} \mathrm{mim}\right]\left[\mathrm{Tf}_{2} \mathrm{~N}\right]$ formation. The decrease in $\left[\mathrm{Tf}_{2} \mathrm{~N}^{-}\right]$concentration, when $\left[\mathrm{C}_{4} \mathrm{mim}\right] \mathrm{Cl}$ is added, leads to a decrease in concentration of protonated $\left[\mathrm{Tf}_{2} \mathrm{~N}^{-}\right]$, and to lower amounts of hydrated $\mathrm{H}\left[\mathrm{Tf}_{2} \mathrm{~N}\right]$ transferred to the IL phase. This result explains the decrease of water solubility in $\left[\mathrm{C}_{4} \mathrm{mim}\right]\left[\mathrm{Tf}_{2} \mathrm{~N}\right]$ contacted with $\left[\mathrm{C}_{4} \mathrm{mim}\right] \mathrm{Cl}$ solution (Fig. 9a). On the other hand, the addition of $\operatorname{Li}\left[\mathrm{Tf}_{2} \mathrm{~N}\right]$ salt results in an increase in $\mathrm{H}\left[\mathrm{Tf}_{2} \mathrm{~N}^{-}\right]$concentration and this effect is more pronounced at higher aqueous acidity. The higher water uptake from aqueous $\mathrm{Li}\left[\mathrm{Tf}_{2} \mathrm{~N}\right]$ solutions is probably caused by higher $\mathrm{H}\left[\mathrm{Tf}_{2} \mathrm{~N}\right]$ extraction (Fig. 9b). The decrease in equilibrium $\left[\mathrm{Tf}_{2} \mathrm{~N}^{-}\right]$concentration at higher aqueous acidity further supports the idea of $\mathrm{H}\left[\mathrm{Tf}_{2} \mathrm{~N}\right]$ extraction (Fig. 10a).

\subsection{Theoretical description of IL solubility in the aqueous phase}

In order to describe the behavior of the latter IL-based biphasic system, a mathematical model for the equilibrium concentrations of anions and cations in the presence of a common ion in the acidic aqueous phase has been developed.

The solubility equilibrium for the ionic liquid in the aqueous phase (Fig. 4a) is expressed as: 

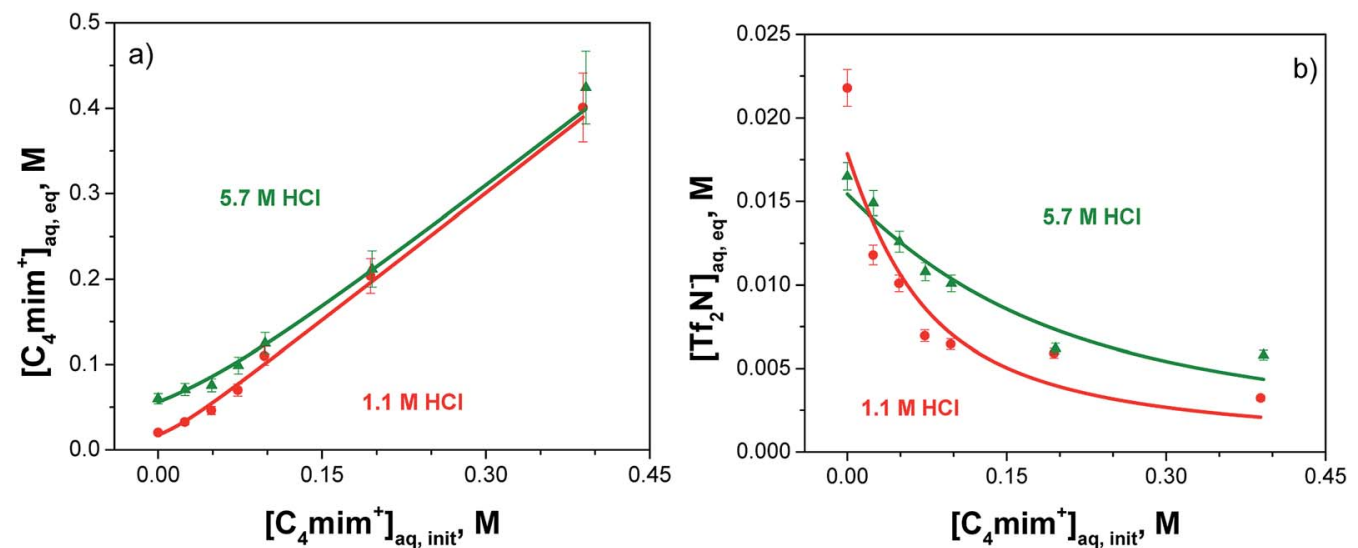

Fig. 11 The equilibrium concentration of $\left[\mathrm{C}_{4} \mathrm{mim}^{+}\right](\mathrm{a})$ and $\left[\mathrm{Tf}_{2} \mathrm{~N}^{-}\right](\mathrm{b})$ in the aqueous hydrochloric acid solutions as a function of concentration of added $\left[\mathrm{C}_{4} \mathrm{mim}\right] \mathrm{Cl}$ salt according to eqn (17) and (18) below.

$$
\left[\mathrm{C}^{+}\right]_{\mathrm{IL}}+\left[\mathrm{A}^{-}\right]_{\mathrm{IL}} \leftrightarrow\left[\mathrm{C}^{+}\right]_{\mathrm{aq}}+\left[\mathrm{A}^{-}\right]_{\mathrm{aq}}
$$

where $\left[\mathrm{C}^{+}\right]$and $\left[\mathrm{A}^{-}\right]$are the cation and anion of the IL, respectively. The equilibrium constant for eqn (2) is defined as solubility product, $K_{\mathrm{sp}}$ :

$$
K_{\mathrm{sp}}=\left[\mathrm{C}^{+}\right]_{\mathrm{aq}}\left[\mathrm{A}^{-}\right]_{\mathrm{aq}}
$$

It is known that the IL anion, $\left[\mathrm{Tf}_{2} \mathrm{~N}^{-}\right]$, in the aqueous acidic phase is partially protonated (Fig. $4 \mathrm{~b}$ ):

$$
\begin{aligned}
\mathrm{H}\left[\mathrm{Tf}_{2} \mathrm{~N}\right]_{\mathrm{aq}} & \leftrightarrow\left[\mathrm{H}^{+}\right]_{\mathrm{aq}}+\left[\mathrm{Tf}_{2} \mathrm{~N}^{-}\right]_{\mathrm{aq}} \\
K_{\mathrm{a}} & =\frac{\left[\mathrm{H}^{+}\right]\left[\mathrm{Tf}_{2} \mathrm{~N}^{-}\right]}{\left[\mathrm{HTf}_{2} \mathrm{~N}\right]}
\end{aligned}
$$

where the acid-dissociation constant $K_{\mathrm{a}}$ is equal to $0.70 \pm 0.04$ mol dm ${ }^{-3} .58$

In the case of a common anion, the charge balance in the aqueous phase before extraction is given by:

$$
\left[\mathrm{Li}^{+}\right]_{\mathrm{aq}, \text { init }}+\left[\mathrm{H}^{+}\right]_{\mathrm{aq}, \text { init }}=\left[\mathrm{Tf}_{2} \mathrm{~N}^{-}\right]_{\mathrm{aq}, \text { init }}+\left[\mathrm{Cl}^{-}\right]_{\mathrm{aq}, \text { init }}
$$

and after extraction is given by:

$$
\left[\mathrm{Li}^{+}\right]_{\mathrm{aq}}+\left[\mathrm{H}^{+}\right]_{\mathrm{aq}}+\left[\mathrm{C}^{+}\right]_{\mathrm{aq}}=\left[\mathrm{A}^{-}\right]_{\mathrm{aq}}+\left[\mathrm{Cl}^{-}\right]_{\mathrm{aq}}
$$

It was shown above that $\mathrm{Cl}^{-}$was not detectably extracted into the IL phase. Thus, $\left[\mathrm{Cl}^{-}\right]_{\mathrm{aq}, \text { init }}=\left[\mathrm{Cl}^{-}\right]_{\mathrm{aq}}$. It was also found that $\left[\mathrm{Li}^{+}\right]_{\mathrm{aq}, \text { init }}=\left[\mathrm{Li}^{+}\right]_{\mathrm{aq}}$. Due to partial protonation of $\left[\mathrm{Tf}_{2} \mathrm{~N}^{-}\right]$, we can write $\left[\mathrm{H}^{+}\right]_{\mathrm{aq}, \text { init }}=\left[\mathrm{H}^{+}\right]_{\mathrm{aq}}+[\mathrm{HA}]_{\mathrm{aq}}$ (to first order, this is correct and simplifies the mathematical model). Therefore, subtraction of eqn (7) from eqn (6) leads to:

$$
[\mathrm{HA}]_{\mathrm{aq}}-\left[\mathrm{C}^{+}\right]_{\mathrm{aq}}=\left[\mathrm{Tf}_{2} \mathrm{~N}^{-}\right]_{\mathrm{aq}, \text { init }}-\left[\mathrm{A}^{-}\right]_{\mathrm{aq}}
$$

and can be rearranged to give:

$$
\left[\mathrm{C}^{+}\right]_{\mathrm{aq}}=\left(1+\left[\mathrm{H}^{+}\right]_{\mathrm{aq}} K_{\mathrm{a}}^{-1}\right)\left[\mathrm{A}^{-}\right]_{\mathrm{aq}}-\left[\mathrm{Tf}_{2} \mathrm{~N}^{-}\right]_{\mathrm{aq}, \text { init }}
$$

In the presence of acid in the aqueous phase, eqn (5) must be modified as

$$
K_{\mathrm{sp}}^{\prime}=\left[\mathrm{C}^{+}\right]\left(\left[\mathrm{A}^{-}\right]+[\mathrm{HA}]\right)=\left[\mathrm{C}^{+}\right]\left[\mathrm{A}^{-}\right]\left(1+\left[\mathrm{H}^{+}\right]_{\mathrm{aq}} K_{\mathrm{a}}{ }^{-1}\right)
$$

Combining eqn (9) and (10) gives

$$
\begin{aligned}
K_{\mathrm{sp}}^{\prime}= & {\left[\left(1+\left[\mathrm{H}^{+}\right]_{\mathrm{aq}} K_{\mathrm{a}}^{-1}\right)\left[\mathrm{A}^{-}\right]_{\mathrm{aq}}\right.} \\
& \left.-\left[\mathrm{Tf}_{2} \mathrm{~N}^{-}\right]_{\mathrm{aq}, \text { init }}\right]\left[\mathrm{A}^{-}\right]\left(1+\left[\mathrm{H}^{+}\right]_{\mathrm{aq}} K_{\mathrm{a}}{ }^{-1}\right)
\end{aligned}
$$

The solution to this quadratic equation in terms of $\left[\mathrm{A}^{-}\right]$and $\left[\mathrm{C}^{+}\right]$gives, respectively

$$
\begin{aligned}
{\left[\mathrm{A}^{-}\right] } & =\frac{\left[\mathrm{Tf}_{2} \mathrm{~N}^{-}\right]_{\text {init }}+\sqrt{\left[\mathrm{Tf}_{2} \mathrm{~N}^{-}\right]_{\text {init }}{ }^{2}+4 K_{\mathrm{sp}}^{\prime}}}{2\left(1+\left[\mathrm{H}^{+}\right]_{\mathrm{aq}} K_{\mathrm{a}}{ }^{-1}\right)} \\
{\left[\mathrm{C}^{+}\right] } & =\frac{-\left[\mathrm{Tf}_{2} \mathrm{~N}^{-}\right]_{\text {init }}+\sqrt{\left[\mathrm{Tf}_{2} \mathrm{~N}^{-}\right]_{\text {init }}{ }^{2}+4 K_{\mathrm{sp}}^{\prime}}}{2}
\end{aligned}
$$

The presence of a common cation leads to the charge balance before extraction:

$$
\left[\mathrm{C}_{4} \mathrm{mim}^{+}\right]_{\mathrm{aq}, \text { init }}+\left[\mathrm{H}^{+}\right]_{\mathrm{aq}, \text { init }}=\left[\mathrm{Cl}^{-}\right]_{\mathrm{aq}, \text { init }}
$$

and after extraction:

$$
\left[\mathrm{H}^{+}\right]_{\mathrm{aq}}+\left[\mathrm{C}^{+}\right]_{\mathrm{aq}}=\left[\mathrm{A}^{-}\right]_{\mathrm{aq}}+\left[\mathrm{Cl}^{-}\right]_{\mathrm{aq}}
$$

Subtraction of eqn (15) from eqn (14) leads to:

$$
[\mathrm{HA}]_{\mathrm{aq}}+\left[\mathrm{C}_{4} \mathrm{mim}^{+}\right]_{\mathrm{aq}, \text { init }}-\left[\mathrm{C}^{+}\right]_{\mathrm{aq}}=-\left[\mathrm{A}^{-}\right]_{\mathrm{aq}}
$$

Combining eqn (16) and (10) gives another quadratic equation, where

$$
\left[\mathrm{A}^{-}\right]=\frac{-\left[\mathrm{C}_{4} \mathrm{mim}^{+}\right]_{\mathrm{init}}+\sqrt{\left[\mathrm{C}_{4} \mathrm{mim}^{+}\right]_{\mathrm{init}}{ }^{2}+4 K_{\mathrm{sp}}^{\prime}}}{2\left(1+\left[\mathrm{H}^{+}\right]_{\mathrm{aq}} K_{\mathrm{a}}{ }^{-1}\right)}
$$

$$
\left[\mathrm{C}^{+}\right]=\frac{\left[\mathrm{C}_{4} \mathrm{mim}^{+}\right]_{\mathrm{init}}+\sqrt{\left[\mathrm{C}_{4} \mathrm{mim}^{+}\right]_{\mathrm{init}}{ }^{2}+4 K_{\mathrm{sp}}^{\prime}}}{2}
$$


Table 4 Fitted $K_{\text {sp }}^{\prime}$ parameters in the systems with $\mathrm{Li}\left[\mathrm{Tf}_{2} \mathrm{~N}\right]$ and $\left[\mathrm{C}_{4} \mathrm{mim}\right] \mathrm{Cl}$ salts. $\left[\mathrm{A}^{-}\right]$and $\left[\mathrm{C}^{+}\right]$refer to which data were used to extract $K_{\text {sp }}^{\prime}$

\begin{tabular}{|c|c|c|c|c|}
\hline \multirow[b]{2}{*}{ Salt } & \multicolumn{2}{|l|}{$1.1 \mathrm{M} \mathrm{HCl}$} & \multicolumn{2}{|l|}{$5.7 \mathrm{M} \mathrm{HCl}$} \\
\hline & {$\left[\mathrm{A}^{-}\right]$} & {$\left[\mathrm{C}^{+}\right]$} & {$\left[\mathrm{A}^{-}\right]$} & {$\left[\mathrm{C}^{+}\right]$} \\
\hline $\begin{array}{l}\mathrm{Li}\left[\mathrm{Tf}_{2} \mathrm{~N}\right] \\
{\left[\mathrm{C}_{4} \mathrm{mim}\right] \mathrm{Cl}}\end{array}$ & $\begin{array}{l}(4.6 \pm 1.2) \times 10^{-4} \\
(2.1 \pm 1.6) \times 10^{-3}\end{array}$ & $\begin{array}{l}(4.7 \pm 0.5) \times 10^{-4} \\
(3.0 \pm 1.9) \times 10^{-4}\end{array}$ & $\begin{array}{l}(1.3 \pm 0.2) \times 10^{-2} \\
(1.4 \pm 0.6) \times 10^{-2}\end{array}$ & $\begin{array}{l}(7.7 \pm 0.3) \times 10^{-3} \\
(3.1 \pm 0.6) \times 10^{-3}\end{array}$ \\
\hline
\end{tabular}

In all cases, the result is a monotonically increasing or decreasing function. Thus, the current model cannot explain the experimental results in Fig. $8 \mathrm{~b}$ due to the non-monotonic behavior of the anions.

The calculated $K_{\text {sp }}^{\prime}$ parameters for Fig. 10 and 11 are given in Table 4. It can be seen that, in principle, the values are in rough agreement between each other for the same group of data. Although the calculated curves do not always fit experimental data points (Fig. 11b), we can conclude that the proposed mathematical model describes the trends of data change well enough to reflect the basic character of the process.

To conclude, the results of the present study give an additional insight into the mutual solubility of water and imidazolium-based ionic liquids in the presence of $\mathrm{H}\left[\mathrm{Tf}_{2} \mathrm{~N}\right]$ and $\mathrm{HCl}$ acids, and $\mathrm{Li}\left[\mathrm{Tf}_{2} \mathrm{~N}\right]$ and $\left[\mathrm{C}_{4} \mathrm{mim}\right] \mathrm{Cl}$ salts in the aqueous phase. The distribution of $\mathrm{H}\left[\mathrm{Tf}_{2} \mathrm{~N}\right]$ plays an important role and should be taken into account for the description of IL-based biphasic systems, and for metal extraction in these kinds of extraction systems. Further development of the analytical procedures, especially for the small variations of $\mathrm{H}^{+}$concentrations at the initially high mineral acid concentrations, is needed to precisely test the proposed mechanism of mutual solubility of water and an IL in biphasic systems HX//IL.

\section{Conclusion}

In this work, novel experimental data on the influence of hydrochloric acid, on the mutual solubility of water and hydrophobic ionic liquids, $\left[\mathrm{C}_{n} \operatorname{mim}\right]\left[\mathrm{Tf}_{2} \mathrm{~N}\right](n=2,4,6$ or 8$)$ and $\left[\mathrm{C}_{3} \mathrm{C}_{1}\right.$ pyrr $]\left[\mathrm{Tf}_{2} \mathrm{~N}\right]$, at room temperature and atmospheric pressure, have been obtained. Hydrochloric acid noticeably enhances water uptake and aqueous IL solubility, and the amount of IL cations dissolved in the acidic aqueous phase is higher than that of anions. For a given hydrochloric acid concentration, the mutual solubility of water and $\mathrm{Tf}_{2} \mathrm{~N}$ based ILs decrease with increasing hydrophobicity of the ILs: $\left[\mathrm{C}_{2} \operatorname{mim}\right]\left[\mathrm{Tf}_{2} \mathrm{~N}\right]>\left[\mathrm{C}_{3} \mathrm{C}_{1}\right.$ pyrr $]\left[\mathrm{Tf}_{2} \mathrm{~N}\right]>\left[\mathrm{C}_{4} \operatorname{mim}\right]\left[\mathrm{Tf}_{2} \mathrm{~N}\right]>$ $\left[\mathrm{C}_{6} \mathrm{mim}\right]\left[\mathrm{Tf}_{2} \mathrm{~N}\right]>\left[\mathrm{C}_{8} \operatorname{mim}\right]\left[\mathrm{Tf}_{2} \mathrm{~N}\right]$. The introduction in the aqueous acidic phase of compounds bearing the same anion with $\mathrm{IL}, \mathrm{H}\left[\mathrm{Tf}_{2} \mathrm{~N}\right]$ acid and $\mathrm{Li}\left[\mathrm{Tf}_{2} \mathrm{~N}\right]$ salt, results in the increase of water solubility in imidazolium-based ILs, while the $\left[\mathrm{C}_{4} \mathrm{mim}\right] \mathrm{Cl}$ salt slightly reduces the water uptake. The salting-out effect of these compounds is dependent on their nature and concentration, and the hydrochloric acid concentration in the aqueous phase. A mathematical model for the equilibrium concentrations of IL anions and cations in the presence of a common ion in the acidic aqueous phase has been developed. The results of this study are of key importance for designing the extraction systems composed of hydrophobic dialkylimidazolium ILs and hydrochloric acid solutions, and for understanding metal extraction mechanisms in these kinds of systems.

\section{Acknowledgements}

The authors thank Maurice Coppe, Dr Lionel Allouche and Dr Bruno Vincent (Institute of Chemistry, University of Strasbourg, France) for the NMR measurements. The present work was financially supported by the Interdisciplinary Mission at the Centre National de la Recherche Scientifique of France (CNRS) in the frame of the project "PHENOM". This material is based upon work supported by the U.S. Department of Energy, Office of Science, Office of Nuclear Physics under Award Number DEFG02-12ER41869/DE-SC0008126. The authors would like to especially thank Dr Clotilde Gaillard (IPNL, Lyon) for fruitful discussions.

\section{References}

1 K. Binnemans, Chem. Rev., 2007, 107, 2592-2614.

2 E. E. Tereshatov, M. Yu. Boltoeva, V. Mazan, M. F. Volia and C. M. Folden III, J. Phys. Chem. B, 2016, 120, 2311-2322.

3 J. P. Hallett and T. Welton, Chem. Rev., 2011, 111, 3508-3576.

4 C. H. C. Janssen, N. A. Macías-Ruvalcaba, M. AguilarMartínez and M. N. Kobrak, Int. Rev. Phys. Chem., 2015, 34, 591-622.

5 P. Wasserscheid and T. Welton, Ionic Liquids in Synthesis, Wiley, 2nd edn, 2008.

6 M. Smiglak, J. M. Pringle, X. Lu, S. Zhang, H. Gao, D. R. MacFarlane and R. D. Rogers, Chem. Commun., 2014, 50, 9228-9250.

7 R. D. Rogers, Nature, 2007, 447, 917-918.

8 R. Jindal and A. Sablok, Curr. Green Chem., 2015, 2, 135-155.

9 P. Wasserscheid and W. Keim, Angew. Chem., Int. Ed., 2000, 39, 3772-3789.

10 R. Ratti, Adv. Chem., 2014, 2014, 16.

11 T. Tsuda and C. L. Hussey, Electrochem. Soc. Interface, 2007, 42-49.

$12 \mathrm{H}$. Ohno, Electrochemical Aspects of Ionic Liquids, John Wiley \& Sons, 2011.

13 D. Han and K. H. Row, Molecules, 2010, 15, 2405-2426.

14 C. Shi, D. Duan, Y. Jia and Y. Jing, J. Mol. Liq., 2014, 200, 191195.

15 S. A. Dharaskar, K. L. Wasewar, M. N. Varma and D. Z. Shende, Sep. Purif. Technol., 2015, 155, 101-109. 
16 T. V. Hoogerstraete, S. Wellens, K. Verachtert and K. Binnemans, Green Chem., 2013, 15, 919-927.

17 M. Villanueva, A. Coronas, J. Garcia and J. Salgado, Ind. Eng. Chem. Res., 2013, 52, 15718-15727.

18 D. M. Fox, J. W. Gilman, A. B. Morgan, J. R. Shields, P. H. Maupin, R. E. Lyon, H. C. D. Long and P. C. Trulove, Ind. Eng. Chem. Res., 2008, 47, 6327-6332.

19 H.-J. Liaw, S.-K. Huang, H.-Y. Chen and S.-N. Liu, Procedia Eng., 2012, 45, 502-506.

20 M. J. Earle, J. M. S. S. Esperança, M. A. Gilea, J. N. C. Lopes, L. P. N. Rebelo, J. W. Magee, K. R. Seddon and J. A. Widegren, Nature, 2006, 439, 831-834.

21 P. Wasserscheid, Nature, 2006, 439, 797.

22 S. Dai, Y. H. Ju and C. E. Barnes, Dalton Trans., 1999, 12011202.

23 A. Stojanovic and B. K. Keppler, Sep. Sci. Technol., 2012, 47, 189-203.

24 S. Pandey, K. A. Fletcher, S. N. Baker and G. A. Baker, Analyst, 2004, 129, 569-573.

25 M. A. R. Martins, C. M. S. S. Neves, K. A. Kurnia, P. J. Carvalho, M. A. A. Rocha, L. M. N. B. F. Santos, S. P. Pinho and M. G. Freire, Fluid Phase Equilib., 2016, 407, 188-196.

26 V. Mazan, I. Billard and N. Papaiconomou, RSC Adv., 2014, 4, 13371-13384.

27 C. Gaillard, V. Mazan, S. Georg, O. Klimchuk, M. Sypula, I. Billard, R. Schurhammer and G. Wipff, Phys. Chem. Chem. Phys., 2012, 14, 5187-5199.

28 S. A. Ansari, P. K. Mohapatra, V. Mazan and I. Billard, RSC Adv., 2015, 5, 35821-35829.

29 N. Papaiconomou, I. Billard and E. Chainet, RSC Adv., 2014, 4, 48260-48266.

30 N. Papaiconomou, S. Genand-Pinaz, J.-M. Leveque and S. Guittonneau, Dalton Trans., 2013, 1979-1982.

31 J. Ranke and A. Othman, Int. J. Mol. Sci., 2009, 10, 1271-1289.

32 C. Kolbeck, J. Lehmann, K. R. J. Lovelock, T. Cremer, N. Paape, P. Wasserscheid, A. P. Fröba, F. Maier and H. P. Steinrück, J. Phys. Chem. B, 2010, 114, 17025-17036.

33 R. L. Gardas, R. G. N. A. Manan, D. W. Rooney and C. Hardacre, Fluid Phase Equilib., 2010, 294, 139-147.

34 M. G. Freire, P. J. Carvalho, R. L. Gardas, I. M. Marrucho, L. M. N. B. F. Santos and J. A. P. Coutinho, J. Phys. Chem. $B, 2008,112,1604-1610$.

35 M. Atanassova, V. Mazan and I. Billard, ChemPhysChem, 2015, 16, 1703-1711.

36 A. Ahosseini and A. M. Scurto, Int. J. Thermophys., 2008, 29, 1222-1243.
37 M. G. Freire, C. M. S. S. Neves, P. J. Carvalho, R. L. Gardas, A. M. Fernandes, I. M. Marrucho, L. M. N. B. F. Santos and J. A. P. Coutinho, J. Phys. Chem. B, 2007, 111, 13082-13089. 38 I. Billard and S. Georg, Helv. Chim. Acta, 2009, 92, 2227-2237. 39 G. F. Pauli, B. U. Jaki and D. C. Lankin, J. Nat. Prod., 2005, 68, 133-149.

40 J. Rodier, L'Analyse de l'eau, DUNOD, Paris, 2009.

41 D. Dupont, D. Depuydt and K. Binnemans, J. Phys. Chem. B, 2015, 119, 6747-6757.

42 J. Rydberg, C. Musikas and G. R. Choppin, Principles and practices of solvent extraction, M. Dekker, 1992.

43 T. Katase, S. Imashuku, K. Murase, T. Hirato and Y. Awakura, Sci. Technol. Adv. Mater., 2006, 7, 502-510.

44 E. S. Stoyanov, K. C. Kim and C. A. Reed, J. Phys. Chem. A, 2004, 108, 9310-9315.

45 Z. Kolarik, Solvent Extr. Ion Exch., 2013, 31, 24-60.

46 C. Gaillard, V. Mazan, S. Georg, O. Klimchuk, M. Sypula, I. Billard, R. Schurhammer and G. Wipff, Phys. Chem. Chem. Phys., 2012, 14, 5187-5199.

47 V. Mazan, I. Billard and N. Papaiconomou, RSC Adv., 2014, 4, 13371-13384.

48 M. A. A. Rocha, C. M. S. S. Neves, M. G. Freire, O. Russina, A. Triolo, J. A. P. Coutinho and L. M. N. B. F. Santos, J. Phys. Chem. B, 2013, 117, 10889-10897.

49 R. Hayes, G. G. Warr and R. Atkin, Chem. Rev., 2015, 115, 6357-6426.

50 K. Shimizu, C. E. S. Bernardes and J. N. Canongia Lopes, J. Phys. Chem. B, 2014, 118, 567-576.

51 Y. Kohno and H. Ohno, Chem. Commun., 2012, 48, 71197130.

52 M. G. Freire, L. M. N. B. F. Santos, A. M. Fernandes, J. A. P. Coutinho and I. M. Marrucho, Fluid Phase Equilib., 2007, 261, 449-454.

53 K. A. Kurnia, C. M. S. S. Neves, M. G. Freire, L. M. N. B. F. Santos and J. A. P. Coutinho, J. Mol. Liq., 2015, 210, 264-271.

54 B. Onghena and K. Binnemans, Ind. Eng. Chem. Res., 2015, 54, 1887-1898.

55 D. Dupont, D. Depuydt and K. Binnemans, J. Phys. Chem. B, 2015, 119, 6747-6757.

56 L. I. N. Tomé, F. T. R. Varanda, M. G. Freire, I. M. Marrucho and J. O. A. P. Coutinho, J. Phys. Chem. B, 2009, 113, 28152825.

57 S. A. Ansari, P. K. Mohapatra, V. Mazan and I. Billard, RSC Adv., 2015, 5, 35821-35829.

58 S. Katsuta, Y. Watanabe, Y. Araki and Y. Kudo, ACS Sustainable Chem. Eng., 2016, 4, 564-571. 